*aMIS View/Print Document Cover Sheet

This document was retrieved from the Boeing ISEARCH System.

Accession \#: D196054401

Document \#: SD-WM-ER-419

Title/Desc:

TANK 241BY105 HEADSPACE GAS \& VAPOR CHARACTERIZATION RESULTS FOR SAMPLES COLLECTED IN $5 / 1994 \& 7 / 1994$ 
Pago 1 of 2 Proj:

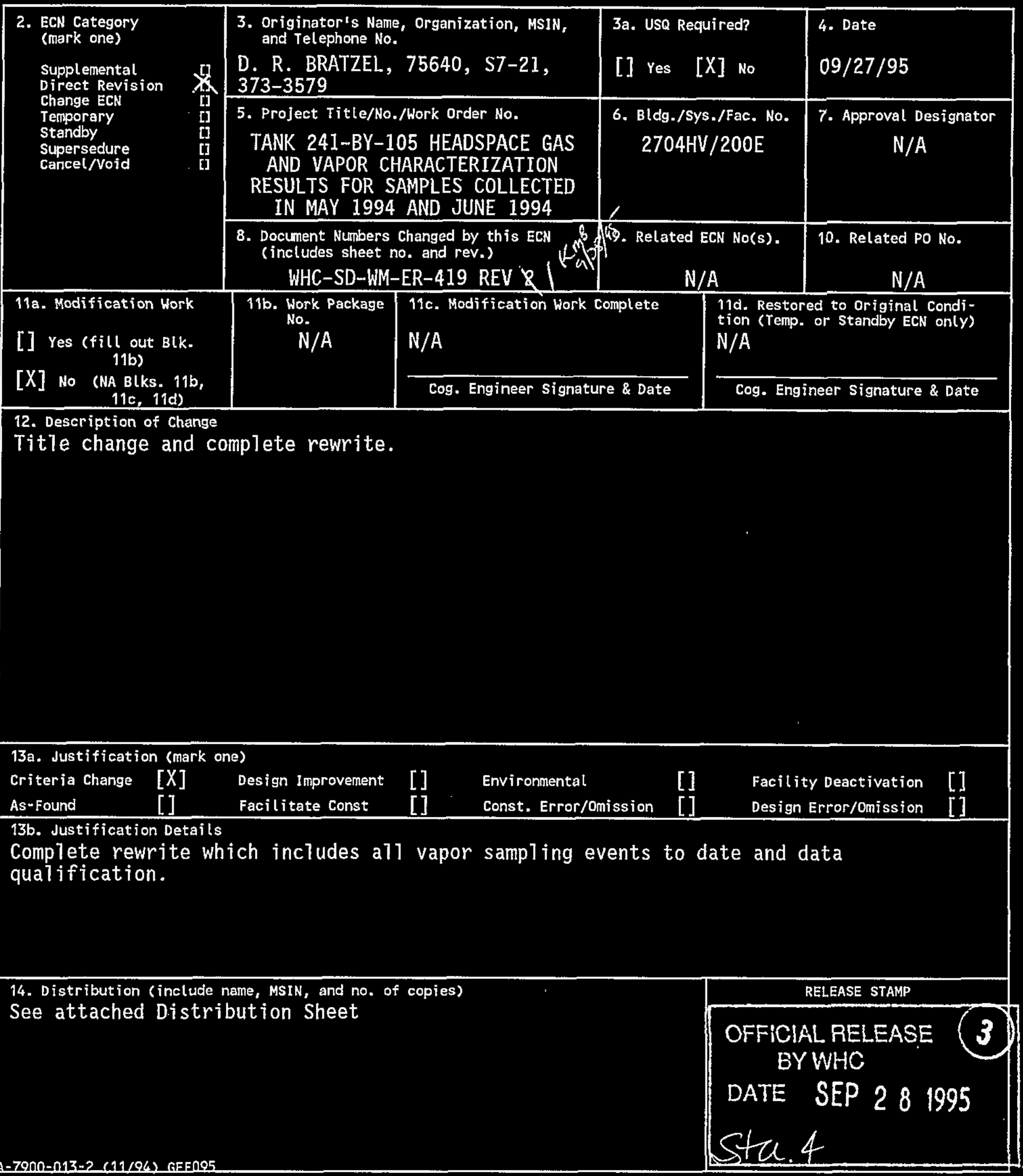




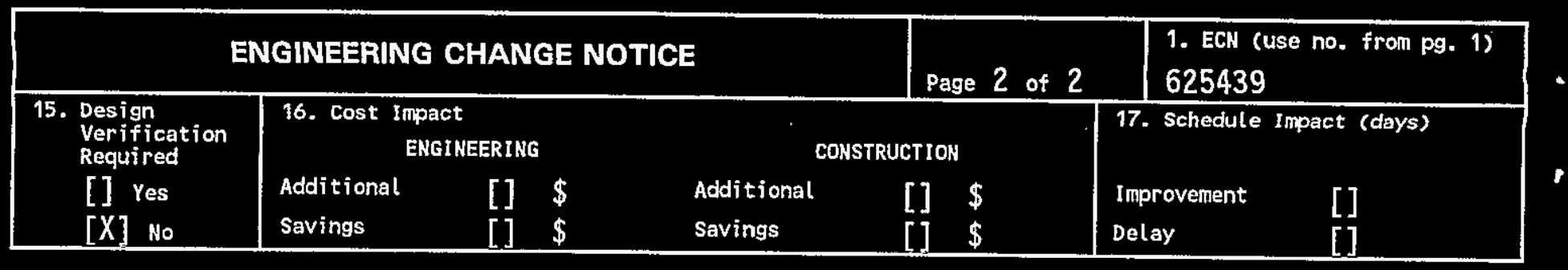

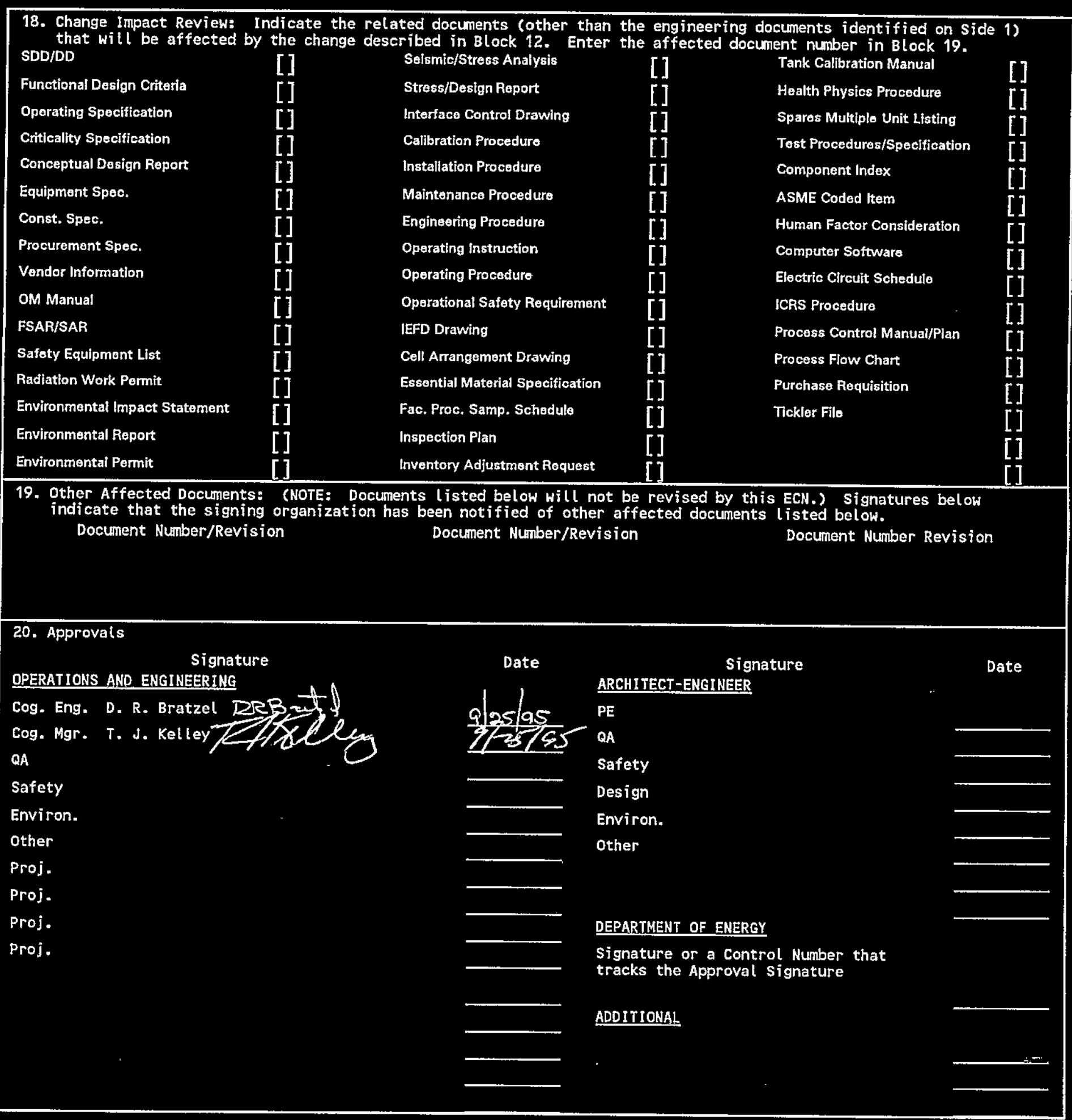




\section{RELEASE AUTHORIZATION}

Document Number: WHC-SD-WM-ER-419, REV 2

Tank 241-BY-105 Headspace Gas and Vapor

Characterization Results for Samples Collected in

May 1994 and July 1994

Release Date: $\quad 9 / 28 / 95$

This document was reviewed following the procedures described in WHC-CM-3-4 and is:

APPROVED FOR PUBLIC RELEASE

WHC Information Release Administration Specialist:
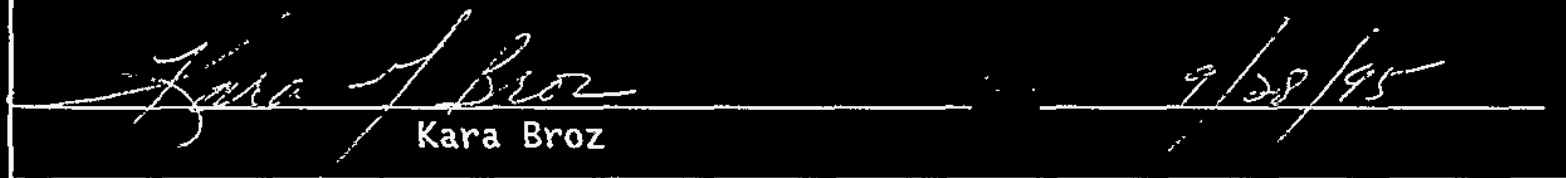

TRADEMARK DISCLAIMER. Reference herein to any specific commercial product, process, or service by trade name, trademark, manufacturer, or otherwise, does not necessarily constitute or imply its endorsement, recommendation, or favoring by the United States Government or any agency thereof or its contractors or subcontractors.

This report has been reproduced from the best available copy. Available in paper copy. Printed in the United States of America. To obtain copies of this report, contact:

Westinghouse Hanford Company - Document Control Services

P.0. Box 1970, Mailstop H6-08, Richland, WA 99352

Telephone: (509) 372-2420; Fax: (509) 376-4989 
<smiles>C1CC1</smiles> 
2. Title

TANK 241-BY-105 HEADSPACE GAS AND VAPOR CHARACTERIZATION RESULTS FOR SAMPLES COLLECTED IN MAY 1994 AND JULY 1994

\section{Key Words}

CHARACTERIZATION OBJECTIVES, TANK HEADSPACE, SAMPLING EVENT, INORGANIC GASES, ORGANIC VAPORS
3. Number

WHC-SD-WH-ER-419
4. Rev No.

2
6. Author

Name:

D. R. BRATZEL

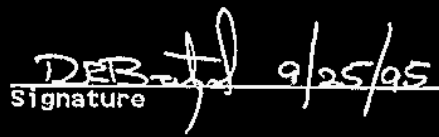

Organization/Charge Code

$75640 / N 4 A B 1$

\section{Abstract}

Significant changes have been made to all of the original vapor characterization reports. This report documents specific headspace gas and vapor characterization results for all vapor sampling events to date. In addition, changes have been made to the original vapor reports to qualify the data based on quality assurance issues associated with the performing laboratories.

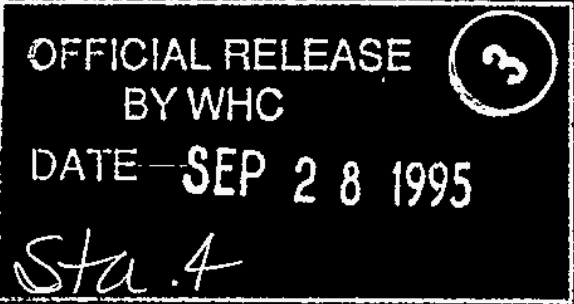




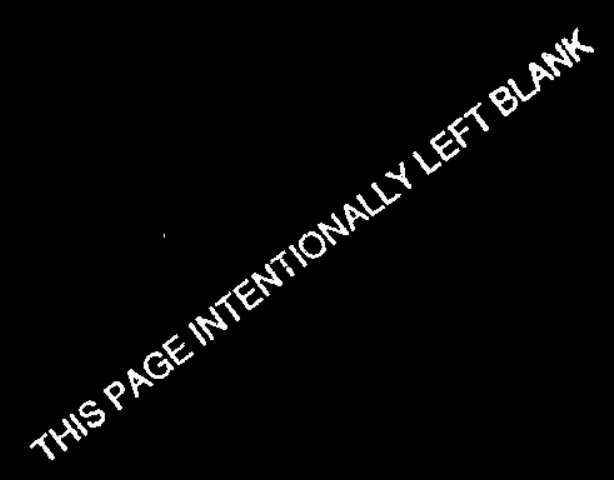




\begin{tabular}{|c|c|c|c|c|}
\hline \multicolumn{2}{|c|}{ RECORD OF REVISION } & \multicolumn{2}{|c|}{$\begin{array}{l}\text { (1) Document Number } \\
\text { WHC-SD-WM-ER-419 }\end{array}$} & Page 1 \\
\hline \multicolumn{5}{|c|}{$\begin{array}{l}\text { (2) Title } \\
\text { TANK 241-BY-105 HEADSPACE GAS AND VAPOR CHARACTERIZATION RESULTS FOR SAMPLES COLLECTED } \\
\text { IN MAY } 1994 \text { AND JULY } 1994\end{array}$} \\
\hline \multicolumn{5}{|c|}{ CHANGE COYTROL RECORD } \\
\hline (3) Revision & (4) Description of Change - Replace, Add, and Delete Pages & \multicolumn{3}{|c|}{ Authorized for Release } \\
\hline 0 & $\begin{array}{l}\text { (7) WHC-SD-WM-ER-419, REV. 0, EDT } 607553 \\
\text { May 31, 1995 }\end{array}$ & (5) Cog. Engr. & (6) 0 & II. Date \\
\hline 1 & $\begin{array}{l}\text { Made editorial changes and added } \\
\text { information in organic vapor chapter. ECN } \\
623542\end{array}$ & & & \\
\hline 2 RS & $\begin{array}{l}\text { Complete revision and title change. ECN } \\
625439\end{array}$ & & & \\
\hline & & & & $v$ \\
\hline & & & & \\
\hline & & & & \\
\hline & & & & \\
\hline & & & & \\
\hline & & & & \\
\hline & & & & \\
\hline & & & & \\
\hline & & & & \\
\hline & & & & \\
\hline & & & & \\
\hline
\end{tabular}





\title{
Tank 241-BY-105 Headspace Gas and Vapor Characterization Results for Samples Collected in May 1994 and July 1994
}

\author{
J. L. Fuckaby \\ Pacific Northwest Laboratories \\ D. R. Bratzel \\ Westinghouse Hanford Company
}

Date Published

September 1995

Prepared for the U.S. Department of Energy Office of Environmental Restoration and Waste Management

Q7) Westinghouse $\begin{aligned} & \text { P.O Box } 1970 \\ & \text { Hanford Company Richland, Washington }\end{aligned}$ 


$$
\text { THSPAE WTENIONALWHETH }
$$




\section{Contents}

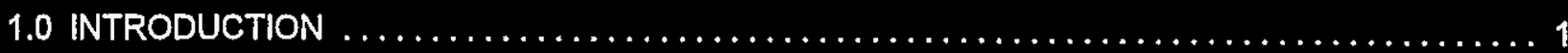

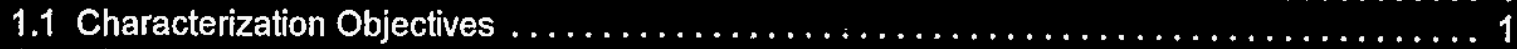

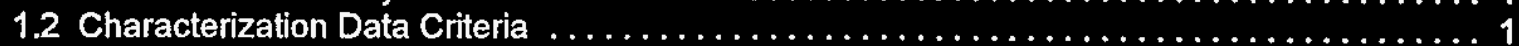

1.3 Sampling Overview . . . . . . . . . . . . . . . . . . . . . . . . . . . . . .

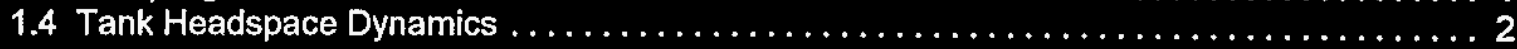

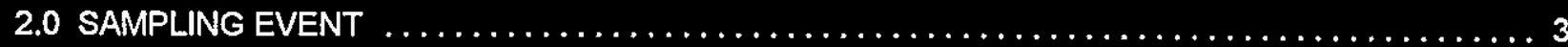

2.1 May 1994 In Situ Sampling Event . . . . . . . . . . . . . . . . . . . . . . . . . . 3

2.2 July 1994 Vapor Sampling System Sampling Event . . . . . . . . . . . . . . . . . . . . . 3

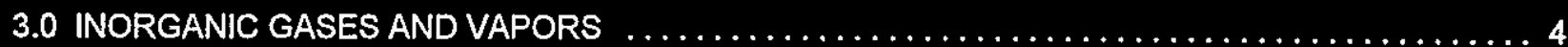

3.1 Ammonia, Hydrogen, and Nitrous Oxide $\ldots \ldots \ldots \ldots \ldots \ldots \ldots \ldots \ldots \ldots$

3.2 Carbon Dioxide and Carbon Monoxide $\ldots \ldots \ldots \ldots \ldots \ldots \ldots \ldots \ldots$

3.3 Nitric Oxide, Nitrogen Dioxide, Water and Tritium $\ldots \ldots \ldots \ldots \ldots \ldots \ldots \ldots$

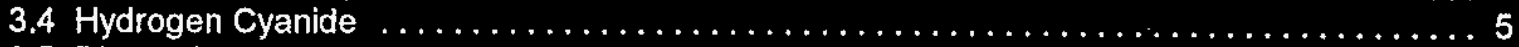

3.5 Discussion of Inorganic Gases and Vapors $\ldots \ldots \ldots \ldots \ldots \ldots \ldots \ldots \ldots \ldots \ldots \ldots$

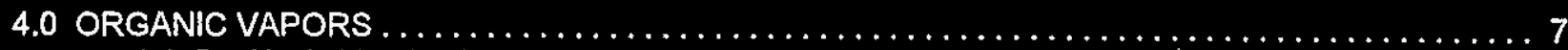

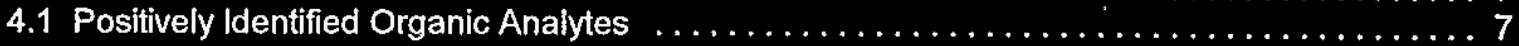

4.2 Tentatively Identified Organic Analytes $\ldots \ldots \ldots \ldots \ldots \ldots \ldots \ldots$

4.3 Total Nonmethane Organic Carbon $\ldots \ldots \ldots \ldots \ldots \ldots \ldots \ldots \ldots$

4.4 Discussion of Organic Analytes $\ldots \ldots \ldots \ldots \ldots \ldots \ldots \ldots \ldots \ldots$

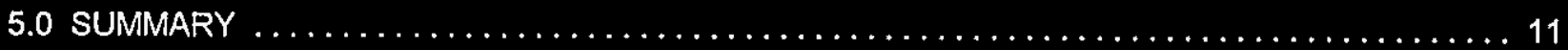

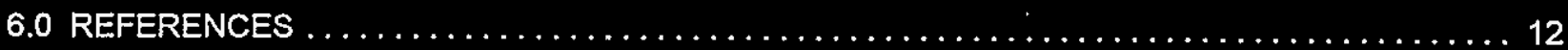

\section{Acronyms and Abbreviations}

$\begin{array}{ll}\text { CES } & \text { consensus exposure standard } \\ \text { EPA } & \text { Environmental Protection Agency } \\ \text { GC } & \text { gas chromatograph } \\ \text { GC/MS } & \text { gas chromatograph/mass spectrometer } \\ \text { ISS } & \text { in situ sampling } \\ \text { LFL } & \text { lower flammability limit } \\ \text { MS } & \text { mass spectrometer } \\ \text { NFPA } & \text { National Fire Protection Association } \\ \text { NPH } & \text { normal paraffinic hydrocarbon } \\ \text { ORNL } & \text { Oak Ridge National Laboratory } \\ \text { PNL } & \text { Pacific Northwest Laboratory } \\ \text { ppmv } & \text { parts per million by volume, } 1 \text { ppmv }=10^{-4} \text { vol\% } \\ \text { TNMOC } & \text { total nonmethane organic carbon } \\ \text { TST } & \text { triple sorbent trap } \\ \text { vol } \% & \text { percent by volume, } 1 \text { vol\% }=10,000 \text { ppmv } \\ \text { VSS } & \text { vapor sampling system } \\ \text { WHC } & \text { Westinghouse Hanford Company }\end{array}$


WHC-SD-WM-ER-419 REV. 2

\section{Acknowledgements}

The author wishes to thank Chris Simonen for her work verifying data and generating tables, and Shas Mattigod for his help with the construction and reviews of this document. 
WHC-SD-WM-ER-419 REV. 2

Tank 241-BY-105 Headspace Gas and Vapor Characterization Results

for Samples Collected in May 1994 and July 1994

\subsection{INTRODUCTION}

\subsection{Characterization Objectives}

Tank BY-105 headspace gas and vapor samples were collected and analyzed to help determine the potential risks of fugitive emissions to tank farm workers. The drivers and objectives of waste tank headspace sampling and analysis are discussed in Program Plan for the Resolution of Tank Vapor lssues (Osborne and Huckaby 1994). This report primarily discusses results from the July 1994 sampling event, but also includes selected results of the May 1994 sampling event. The tank BY-105 headspace was sampled in May 1994 in accordance with Safety Assessment for Gas Sampling All Ferrocyanide Tanks (Farley 1991), and in July 1994 in accordance with Data Quality Objectives for Generic In-Tank Health and Safety lssue Resolution (Osborne et al. 1994).

\subsection{Characterization Data Criteria}

Data Quality Objectives for Generic In-Tank Health and Safety Issue Resolution describes parameters for data collection to ensure appropriate conclusions can be drawn from the data. Tank headspace characterization data were collected to help in the evaluation of 1) headspace flammability, and 2) identification and quantification of compounds of toxicological concern.

Single Shell Tank Interim Operational Safety Requirements (Dougherty 1995) specifies that combustible constituents in tank headspaces be maintained below $25 \%$ of the lower flammability limit (LFL). This essentialiy agrees with National Fire Protection Association requirements that combustible concentrations be maintained at or below $25 \%$ of the LFL (NFPA 1992). Current governing operating specifications for Watchlist tanks, such as tank BY-105, specify that combustible constituents be maintained at or below $20 \%$ of the LFL (WHC 1995a).

Headspace characterization data are used by Westinghouse Hanford Company (WHC) Tank Waste Remediation Systems Industrial Hygiene as source term data in the industrial hygiene strategy to protect workers from tank fugitive emissions. Because selection of worker protective equipment must be based on industrial hygiene monitoring of the work place and not on source term data (29 CFR 1910.120), tank headspace characterization data can not be used for this purpose. Furthermore, because there are mechanisms by which headspace constituents can be either diluted or concentrated as they are released to the atmosphere, the headspace characterization data should not be considered to be representative of emissions at the point of emission.

These statements notwithstanding, the data quality objectives document specifies that the industrial hygiene group be advised if constituents with toxicological properties exceed $50 \%$ of the appropriate consensus exposure standard (CES) for non-carcinogens, or $10 \%$ of the appropriate CES for carcinogens. A CES is defined as the most stringent of known regulatory or recommended toxicological values for the workplace (Osborne et al. 1994). 


\subsection{Sampling Overview}

Tank BY-105 was vapor sampled in May 1994 using the in situ sampling (ISS) method, and again in July 1994 using the more robust vapor sampling system (VSS) method. Because the ISS sample volume flow measurement used during the May 1994 event was inherently less accurate than that of the VSS, the sorbent trap samples from the ISS event are not considered to be equivalent to those from the VSS sampling event (Huckaby et al. 1995). Furthermore, there are other descrepencies between results from the ISS and VSS methods that are not understood (Huckaby 1994a), and until the ISS method has been validated and the descrepencies resolved, results from early ISS events should be considered suspect.

Nevertheless, a brief description of the ISS event and hydrogen cyanide sampling results from the May 1994 ISS event are presented below, because this analyte was not sampled for during the VSS event. Huckaby et al. (1995) describe the bases for using the ISS method for hydrogen cyanide, and why it was not sampled for during the VSS event. All other results presented here are from the July 1994 VSS sampling event.

Samples collected are thought to have been representative of the tank headspace when the tank was sampled (Meacham et al. 1995), and sample analyses were designed to provide a reasonably accurate and complete characterization of the significant headspace constituents. No assessment has been made of how the tank BY-105 headspace composition changes with time, though studies of tank C-103 suggest that composition changes probably occur very slowly in passively ventilated tanks, such as tank BY-105 (Huckaby and Story 1994).

\subsection{Tank Headspace Dynamics}

Tank BY-105 is the second tank in a 3-tank cascade with tanks BY-104 and BY-106. It is connected to both tanks BY-104 and BY-106 via a 7.4-cm (2.9-in.) inside diameter, 7.6-m (25-ft) long underground cascade lines. Since these cascade lines connect the headspaces of these tanks, gases and vapors originating from the wastes in tank BY-104 or BY-106 may be transferred to tank BY-105 (unless the cascade lines are obstructed).

The cascade of tanks BY-104, BY-105, and BY-106 is passively ventilated, which means that the tanks are allowed to exhale air, waste gases, and vapors as the barometric pressure falls, and inhale ambient air as the barometric pressure rises. Each of these tanks has its own filtered breather riser. Barometric pressure typically rises and falls on a diurnal cycle, producing an average daily exchange of air equal to about $0.46 \%$ of each tank headspace (Huckaby 1994b). Changes in the concentrations of tank headspace constituents due to barometric pressure changes are consequently very slow. 


\subsection{SAMPLING EVENT}

\subsection{May 1994 In Situ Sampling Event}

Tank BY-105 was sampled using ISS methods on May 9, 1994 by WHC Sampling and Mobile Laboratories. This sampling was conducted to satisfy requirements of Safety Assessment for Gas Sampling All Ferrocyanide Tanks (Farley 1991). Samples were collected from a point approximately $6.7 \mathrm{~m}$ below the top of the flange on riser 12A, between 5:00 p.m. and 6:00 a.m.

Huckaby et al. (1995) give a general description of the ISS method and equipment. Pingel (1994) provides field sampling information for the tank BY-105 May 1994 ISS event, and Mahon (1995) provides revised sample volume measurements. In addition to the hydrogen cyanide and hydrogen gas results presented below, McVeety et al. (1995a) provide sample preparation and analysis results for selected organic and inorganic vapors, and Rasmussen (1994a) provide SUMMA ${ }^{T M}$ canister analyses for selected gases.

\subsection{July 1994 Vapor Sampling System Sampling Event}

Headspace vapor samples were collected from tank BY-105 using the VSS on July 7, 1994 by WHC Sampling and Mobile Laboratories (WHC 1995b). Sample collection and analysis were performed as directed by the sample and analysis plan (Appendix A, WHC 1995b). The tank headspace temperature was determined to be $26^{\circ} \mathrm{C}$. Air from the tank BY-105 headspace was withdrawn via a heated sampling probe mounted in riser 10A, and transferred via heated tubing to the VSS sampling manifold. All heated zones of the VSS were maintained at approximately $65^{\circ} \mathrm{C}$.

Sampling media were prepared and analyzed by WHC, Oak Ridge National Laboratories (ORNL), Pacific Northwest Laboratories (PNL), and Oregon Graduate Institute of Science and Technology (OGIST) through a contract with Sandia National Laboratories. The 46 tank air samples and 2 ambient air control samples collected are listed in Table 2-1 by analytical laboratory. Table 2-1 also lists the 10 trip blanks provided by the laboratories.

A general description of vapor sampling and sample analysis methods is given by Huckaby et al. (1995). The sampling equipment, sample collection sequence, sorbent trap sample air flow rates and flow times, chain of custody information, and a discussion of the sampling event itself are given in WHC 1995b. 


\subsection{INORGANIC GASES AND VAPORS}

Analytical results of sorbent trap and SUMMA ${ }^{T M, 1}$ canister tank air samples for selected inorganic gases and vapors are given in Table 3-1 in parts per million by volume (ppmv) in dry air. The concentration of water vapor given in Table 3-1 has been adjusted to tank conditions as given in Section 3.3. Inorganic analyte sorbent traps were prepared and analyzed by PNL, and SUMMA ${ }^{\mathrm{TM}}$ canisters were analyzed for inorganic analytes by OCIST. Reports by PNL (MCVeety et al. 1995a) and OGIST (Rasmussen 1994b) describe sample preparation and analyses.

All inorganic sorbent trap samples from the May 1994 and July 1994 sampling events were analyzed by PNL within 52 and 21 days, respectively, of sample collection (Ligotke 1995). These samples were prepared and analyzed under PNL quality assurance impact level 3 guidelines.

WHC delayed shipment of SUMMA ${ }^{T M}$ canister samples from the July 1994 to OGIST, so analyses at OGIST were not begun until 67 days after the samples were collected. This exceeded the administratively chosen 60-day holding time limit of the WHC quality assurance project plan. Because OGIST did not have a WHCapproved quality assurance project plan in place when samples were analyzed, the OGIST data should be considered secondary results. In Table 3-1 and elsewhere in this report, the OGIST data are bracketed to distinguish them as secondary.

\subsection{Ammonia, Hydrogen, and Nitrous Oxide}

The reported ammonia concentration in the headspace of tank BY-105 was 43 ppmv. Ammonia concentrations at this level are not uncommon in the waste tank headspaces, and have been observed to be as high as 1080 ppmv in tank BY-108 (McVeety et al. 1995b). The 43 ppmv ammonia concentration in tank BY-105 is lower than that in most other passively ventilated tanks that have been sampled, but within the normal range. Given the LFL of ammonia in air is about $15 \%$ by volume (vol\%), the measured 43 ppmv corresponds to less than $0.04 \%$ of the LFL, and does not contribute appreciably to the flammability of the headspace.

Analysis of hydrogen in SUMMA ${ }^{\text {TM }}$ canister samples from the July 1994 was not reported by OGIST. The 3 SUMMA ${ }^{\text {TM }}$ canister samples from the May 1994 ISS event were reported by OGIST to have an average [47.9 ppmv] of hydrogen. In general, hydrogen is of concern as a fuel. The measured [47.9 ppmv] of hydrogen in tank BY-105, however, represents only about $0.1 \%$ of the LFL for hydrogen in air, and is not a flammability concern at this level.

Nitrous oxide in tank BY-105 was measured by OGIST to be [ $49.5 \mathrm{ppmv}$ ]. This is a relatively low concentration of nitrous oxide compared to other passively ventilated tanks, though it is within the range of typical values. Table 3-2 lists this and other constituents of tanks BY-104, BY-105, and BY-106 for comparison. Under proper conditions, nitrous oxide can serve as an oxidizer to support combustion. However, Cashdollar et al. (1992) found that nitrous oxide had no significant effect on the flammability of hydrogen and air mixtures for hydrogen concentrations less than 20 vol\%, and that "small amounts of nitrous oxide (relative to air) do not appear to have much effect on the flammability". Their results suggest the measured nitrous oxide concentration is much too low to have a significant effect on the flammability of the tank BY-105 headspace.

1 SUMMA is a trademark of Molectrics, Inc., Cleveland, Ohio. 


\subsection{Carbon Dioxide and Carbon Monoxide}

The average measured headspace carbon dioxide concentration, 94 ppmv, is markedly lower than normal ambient air concentrations of about 350 to 400 ppmv. Carbon dioxide introduced by air exchange with the atmosphere is readily absorbed by caustic supernatant and interstitial liquids of the waste tanks, and converted to carbonate in solution. It is reasonable to expect the level of carbon dioxide in a tank headspace will therefore depend on the tank's breathing rate, and the $\mathrm{pH}$ and surface area of aqueous waste (i.e., supernate, interstitial liquid, and condensate) in the tank.

Carbon monoxide in the tank BY-105 headspace, at about [0.38 ppmv], is above its normal concentration in ambient air, where it typically is about 0.05 to $0.15 \mathrm{ppmv}$. Carbon monoxide may be a decomposition product of organic waste in the tank. Tanks known to have significantly higher organic vapor concentrations have also been observed to have higher carbon monoxide concentrations.

\subsection{Nitric Oxide, Nitrogen Dioxide, Water and Tritium}

Nitric oxide and nitrogen dioxide concentrations in the tank BY-105 headspace were determined to be 0.10 ppmv and $\leq 0.02$ ppmv, respectively. These are both acid gases that would have very low equilibrium concentrations above the high $\mathrm{pH}$ interstitial liquid in tank BY-105. The measurable presence of nitric oxide is not uncommon in waste tank headspaces, and may be due to its formation from oxygen and nitrogen in the radiation field of the headspace. These constituents could potentially serve as oxidizers to support combustion, but at the measured concentrations would have a negligible effect on the flammability of the tank BY-105 headspace.

The water vapor concentration of tank BY- 105 was determined to be about $14.9 \mathrm{mg} / \mathrm{L}$ at the measured headspace temperature of $26^{\circ} \mathrm{C}$ and pressure of $991 \mathrm{mbar}(745 \mathrm{torr}),($ WHC 1995b). This corresponds to water vapor partial pressure of $20.6 \mathrm{mbar}(15.5$ torr $)$, to a dew point of $18.0^{\circ} \mathrm{C}$, and to a relative humidity of about $61 \%$.

Tritium was tested for using silica gel sorbent traps. It is assumed that tritium produced by the waste combines with hydroxide ions to form tritium-substituted water. Evaporation of the tritium-substituted water would then result in airborne radioactive contamination. Silica gel sorbent traps adsorb virtually all (normal and tritium-substituted) water vapor from the sampled tank air, and are analyzed at the WHC 222-S laboratory. Analysis of the silica gel indicated the total activity of the headspace to be below $50 \mathrm{pCi} / \mathrm{L}$ (WHC 1995b).

\subsection{Hydrogen Cyanide}

Analysis of the hydrogen cyanide specific sorbent traps indicated the concentration of this analyte to s. $0.005 \mathrm{ppmv}$ in all 3 samples. The absence of hydrogen cyanide at measurable concentrations is consistent with the expectation that an acid gas, such as hydrogen cyanide, would not exist at significant concentrations above the caustic waste in tank BY-105. No hydrogen cyanide has been detected in any of the 10 waste tank headspaces sampled for this analyte (Huckaby et al. 1995).

\subsection{Discussion of Inorganic Gases and Vapors}

Aside from water vapor and carbon dioxide, the most abundant waste constituents in the tank BY-105 headspace are ammonia, hydrogen, and nitrous oxide. These have been detected in most tank 
headspaces sampled to date, and usually are the dominate waste species. As indicated in Table 3-2, has the lowest concentrations of ammonia and nitrous oxide in the tank BY-104, BY-105, and BY-106 cascade.

The relative standard deviations of the inorganic gas and vapor results given in the last column in Table 3-1 are very good. Relative standard deviations range from $0.6 \%$ for nitrous oxide to $27 \%$ for nitric oxide. The nitric oxide precision is relatively poor because the quantities measured are close to the level of inherent contaminant in the samples. Because the precision reported depends both on sampling parameters (e.g., sample flow rate and flow time for sorbent traps) and analytical parameters (e.g., sample preparation, dilutions, etc.), the small relative standard deviations suggest proper control was maintained both in the field and in the laboratories.

As discussed briefly in Section 1.4, it is possible that gases and vapors generated by the waste in tanks BY104 and BY-106 could be transferred to tank BY-105 via the cascade lines. If significant exchange of selected inorganic gases and vapors were taking place between adjacent tanks, either their headspace compositions would be very similar (if the exchange was mutual), or all constituents detected in one tank would be at or equal or higher concentrations in the other tank (if air flowed predominantly from 1 tank to the other). Data given in Table 3-2 do not clearly indicate the presence or lack of air exchange between tank BY-105 and either tank BY-104 or BY-106. 


\subsection{ORGANIC VAPORS}

Organic vapors in the tank BY-105 headspace were sampled using SUMMA ${ }^{T M}$ canisters, which were analyzed at PNL, and triple sorbent traps (TSTS), which were analyzed by ORNL. None of the positively or tentatively identified organic analytes were at or above levels of concern. Both laboratories used a gas chromatograph (GC) equipped with a mass spectrometer (MS) detector to separate, identify, and quantitate the analytes. Descriptions of sample device cleaning, sample preparations, and analyses are given by Jenkins et al. (1994) and Pool et al. (1995). A quantitative measurement of the total organic vapor concentration by the U.S. Environmental Protection Agency (EPA) task order 12 (TO-12) method was also performed by OGIST (EPA 1988, Rasmussen 1994b).

SUMMA ${ }^{\mathrm{TM}}$ sample results by PNL should be considered to be the primary organic vapor data for tank BY105. These results were produced at PNL quality assurance impact level 3 , and all PNL analyses were completed 19 days after sample collection (Ligotke 1995), well within the administratively chosen 60-day holding time (Keller 1994). No study has been performed to determine the stability of organic analytes in SUMMA ${ }^{T M}$ canisters in the chemical matrix of waste tank samples.

ORNL analyses of TST samples from this and other waste tanks generally agree with, support, and augment the SUMMA ${ }^{\mathrm{TM}}$ sample results. However, because certain WHC quality assurance requirements were not satisfied by ORNL, the quality assurance assessment of ORNL by Hendrickson (1995) should be reviewed before results unique to the TST samples are used for decision making.

All TSTs prepared by ORNL had 3 surrogate compounds added to evaluate sample matrix effects, potential handling, storage, and shipment problems, and analytical instrumentation performance (Jenkins et al. 1995a). ORNL evaluated the surrogate recoveries using a statistical approach similar to that prescribed by SW 846 Method 8260 A Volatile Organic Compounds by Gas ChromatographyMass Spectrometry (GCMS) Capillary Column Technique (EPA 1992). Using this approach, ORNL reported that all surrogates had standard deviation values within the $95 \%$ confidence interval for variance, indicating that no bias was introduced in the measurement of analyte quantities (Jenkins 1995a).

\subsection{Positively Identified Organic Analytes}

Positive identification of organic analytes using the methods employed by PNL and ORNL involves matching the GC retention times and MS data from a sample with that obtained by analysis of standards. The concentration of an analyte in the sample is said to be quantitatively measured if the response of the GCMS has been established at several known concentrations of that analyte (i.e., the GC/MS has been calibrated for that analyte), and the MS response to the analyte in the sample is between the lowest and highest responses to the known concentrations (i.e., the analyte is within the calibration range).

ORNL and PNL were assigned different lists of organic compounds, or target analytes, to positively identify and measure quantitatively. The ORNL target analyte list was derived from a review of the tank C-103 headspace constituents by a panel of toxicology experts (Mahlum et al. 1994). The PNL target analyte list included 40 compounds in the Environmental Protection Agency (EPA) task order 14 (TO-14) method, which are primarily halocarbons and common industrial solvents (EPA 1988), plus 14 analytes selected mainily from the toxicology panel's review of vapor data on tank C-103.

Given in Table 4-1 are the organic compounds positively identified and quantitated in SUMMA ${ }^{\text {TM }}$ canister samples by PNL. PNL performed analyses according to the EPA TO-14 methodology (EPA 1988, Pool et al. 1995). Only 4 of the 40 TO-14 analytes were observed to be above the 0.002 ppmv quantitation limit of the analyses. Averages reported are from analyses of 3 SUMMA ${ }^{\mathrm{TM}}$ canister samples except where noted. The OGIST measurement of methane is also included in Table 4-1. 
ORNL positively identified 26 of 27 analytes selected by WHC, (1 analyte, 1,1-dichloroethene, was below its detection limit). Despite calibration of the instrument over about a 20-fold concentration range, 19 of the 26 positively identified compounds were measured to be outside of the calibration range in at least 1 of the TST samples. The 7 positively identified compounds which were measured to be within the instrument calibration range, and consequently were quantitated, are given in Table 4-2 with their reported 4-TST average concentrations. These 19 positively identified anaiytes which were not quantitated are listed in Tables 4-3 and 4-4. One compound, butanal, is given in Table 4-4 because analyses were performed after the ORNL practical holding time for this compound was exceeded. Data in Tables 4-3 and 4-4 may not be accurate to within $\pm 30 \%$ as speciiied by Burnum (1995).

The ORNL practical holding time is defined as the holding time for which there is a $15 \%$ risk that the concentration of an analyte in the sample will be below its initial concentration (Jenkins et al. 1995). The reported practical holding time of butanal is 1 day, and the TST samples were not analyzed until 8 days after being collected (Jenkins 1995b). It should be noted that the analyses were performed before the holding time study, and that the contractual holding time for the TST samples was 60 days.

Table 4-5 lists the 3 analytes common to both the ORNL and PNL analyses (dichloromethane, benzene, and toluene) and their concentrations measured in SUMMA'M and TST samples. The ORNL and PNL results differ by more than the allowed $\pm 30 \%$ analytical accuracy, however, this difference is reasonable given that fundamentally different sampling devices and analytical methods were used. Each of these analytes is present at only trace levels.

The 3 most abundant organic compounds in the tank BY-105 headspace are methane, 1-butanol, and acetone. At [3.8 ppmv], the methane concentration is about 2 times higher than its normal ambient air concentration. Methane is probably formed during the chemical and radiolytic degradation of organic wastes in the tank. Methane is not a constituent of toxicological concern, and its LFL in air is about 5 vol\%. This places the $3.8 \mathrm{ppmv}$ of methane in tank BY-105 at about $0.008 \%$ of its LFL. 1-Butanol, at $0.70 \mathrm{ppmv}$, and propanone, at 0.25 ppmv, similarly present virtually no flammable or toxicological risks.

\subsection{Tentatively Identified Organic Analytes}

In addition to the target analytes, the ORNL and PNL analytical procedures allow the tentative identification of other organic compounds. Tentative identification of analytes was performed by comparing the MS molecular fragmentation patterns with a library of known MS fragmentation patterns. This method allows an organic analyte to be identified (with reasonable certainty) as an alkane, a ketone, an aldehyde, etc., and may also determine its molecular weight. The method usually does not, however, allow the unambiguous identification of structural isomers, and this ambiguity increases with analyte molecular weight. Using this method, many analytes can be tentatively identified with reasonable confidence without having to inject each into the GC/MS to determine their GC retention times or specific MS patterns.

By the nature of the sampling devices, virtually alt organic vapors present in the tank headspace are collected by both TST and SUMMA ${ }^{\text {TM }}$ samples. Analyses of the samples are designed to recover, separate, and identify the organic vapors in the samples. TSTs are not good for collecting highly volatile compounds (i.e., molecules more volatile than propane), but are quite good for most others. In contrast, the recovery of very low volatility compounds (e.g., molecules with more than about 15 carbon atoms) and some polar compounds with moderate volatility (e.g., butanal) from SUMMA ${ }^{\mathrm{TM}}$ samples has been problematic.

The organic compounds tentatively identified in SUMMA ${ }^{\mathrm{TM}}$ canister samples by PNL are listed, with their estimated concentrations, in Table 4-6. Compounds are listed in Table 4-6 in the order by which they 


\section{WHC-SD-WM-ER-419 REV. 2}

eluted chromatographically, and only non-zero results are included in the reported averages. The list of tentatively identified compounds detected in TST samples, and their estimated concentrations, is given in Table 4-7. Compounds are listed in Table 4-7 according to the order by which the eluted chromatographically. The averages reported by ORNL in Table 4-7 are all 4-sample averages, and if an analyte was not detected in a sample, its concentration in that sample was considered to be zero for averaging purposes. Estimated concentrations are in $\mathrm{mg} / \mathrm{m}^{3}$, based on dry air at $0^{\circ} \mathrm{C}$ and $1.01 \mathrm{bar}$.

Because the list of tentatively identified organic compounds in TST samples is particularly long and locating any given compound may be difficult, the list has been sorted alphanumerically by compound name in Table 4-8. Table 4-9 gives the same list, sorted in order of decreasing estimated concentration. Numbers in the first columns of Tables 4-8 and 4-9 (Cmpd $\$)$ identify the location of the compound in Table 4-7.

The PNL and ORNL methods used to tentatively identify and estimate concentrations are described by Jenkins et al. (1994) and Pool et al. (1995), respectively, and should be reviewed before this data is used for decision making. Results in Tables 4-6 through 4-9 are presented in terms of observed peaks, and are not adjusted for the occurrence of split chromatographic peaks (e.g., Cmpd \# 3, 4, and 5 in Table 4-7). In these instances, the estimated concentration of a compound split into multiple peaks is simply the sum of the individual peak estimates.

Concentrations given in Tables 4-6 through 4-9 should be considered rough estimates. The proper quantitation of all observed analytes is outside the scope and budget of these analyses, and the estimation of concentrations involves several important assumptions. The validity of each assumption depends on the analyte, and such factors as the specific configuration of the analytical instrumentation.

\subsection{Total Nonmethane Organic Carbon}

OGIST measured the TNMOC concentration in 3 SUMMA ${ }^{T M}$ canister samples using the EPA TO- 12 method (Rasmussen $1994 \mathrm{~b}$ ). The sample mean was $\left[12.7 \mathrm{mg} / \mathrm{m}^{3}\right]$, with a standard deviation of $\left[0.4 \mathrm{mg} / \mathrm{m}^{3}\right]$. As indicated in Table 3-2, the TNMOC concentration is much lower in tank BY-105 than in tank BY-104, but about the same as in tank BY-106.

\subsection{Discussion of Organic Analytes}

Some of the compounds listed in Tables 4-1 through 4-9 were introduced to the tank with process waste streams, and are detected in the headspace because the original inventory has not been completely evaporated or degraded. Examples of these are tributyl phosphate, which was used as an extractant in several Hanford processes; dibutyl butylphosphonate, which was a contaminant of tributyl phosphate; and the semivolatile normal paraffinic hydrocarbons (NPHs), (i.e., n-undecane, n-dodecane, n-tridecane, and npentadecane) and branched and cyclic alkanes (e.g., methylated decahydroniaphthalenes, cyclopentanes, and cyciohexanes) with similar boiling points that were used as a diluent for tributyl phosphate. The specific presence of the decahydronaphthalenes and cyclohexanes, which were not observed in tank C-103 samples, is an indication of their different waste histories.

Most of the compounds in Tables 4-1through 4-9, however, are believed to be chemical reaction and radiolytic reaction products of the semivolatile or nonvolatile organic waste stored in the tank. Specifically, 1-butanol is known to be formed by the hydrolysis of tributyl phosphate, and it has been suggested that the alcohols, aldehydes, ketones, nitriles, alkenes, and short chain alkanes are all degradation products of NPHs. 


\section{WHC-SD-WM-ER-419 REV. 2}

Examination of the compounds listed in Tables 4-1 through 4-9 suggests many of the volatile species (presumed to be degradation products of the NPHs) have functional groups on the molecule's first or second carbon atom. For example, most alkenes listed have their double bond between the first and second carbon atoms, and ketones generally have the double bonded oxygen atom on the second carbon atom.

As observed in other NPH-containing waste tanks, there are many small cyclic compounds, specifically cyclopropanes, cyclopentanes, and furans. The presence of these suggest that organic radicals, formed in the radiation field of the tank, play a role in the degradation of the semivolatile compounds. 


\subsection{SUMMARY}

The tank BY-105 headspace was sampled in May 1994 and July 1994 for gases and vapors to address flammability and industrial hygiene concerns. Results unique to the May 1994 event and essentially all results from the July 1994 event have been reported. It was determined that no headspace constituents exceeded the flammability or industrial hygiene notification limits specified in the current Vapor Sampling and Analysis Plan (Homi 1995). 



\subsection{REFERENCES}

29 CFR 1910.120, 1993, "Hazardous Waste Operations and Emergency Response", Code of Federal Regulations.

Burnum, S. T., 1995, Qualification of Reported WHC Vapor Program Data, (letter 95-CHD-065 to president, Westinghouse Hanford Company, August 18), Department of Energy, Richland Operations Office, Richland, Washington.

Cashdollar, K. L..,M. Hertzberg, I. A. Zlochower, C. E. Lucci, G. M. Green, and R. A. Thomas, 1992, Laboratory Flammability Studies of Mixtures of Hydrogen, Nitrous Oxide, and Air, WHC-SD-WMES-219 Rev. 0, Westinghouse Hanford Company, Richland, Washington.

Dougherty, L. F., 1995, Single Shell Tank Interim Operational Safety Requirements, WHC-SD-WM-OSR005 Rev. 0, Westinghouse hanford company, Richiland, Washington.

EPA 1988, Compendium of Methods for the Determination of Toxic Organic Compounds in Ambient Air, PB90-127374, U.S. Environmental Protection Agency, Washington, D.C.

EPA 1992, Test Methods for Evaluating Solid Waste, SW-846 Rev. 1, U.S. Environmental Protection Agency, Washington, D.C.

Farley, W. G., 1991, Safety Assessment for Gas Sampling All Ferrocyanide Tanks, WHC-SD-WM-SAD-009 Rev. 2, Westinghouse Hanford Company, Richland, Washington.

Hendrickson, R. W., 1995, Tank Vapor Characterization Oak Ridge National Laboratories Quality Assurance Assessment, TWRSQA-95-0012, Westinghouse Hanford Company, Richland, Washington.

Homi, C. S., 1995, Vapor Sampling and Analysis Plan, WHC-SD-WM-TP-335 Rev. OG, Westinghouse Hanford Company, Richland, Washington.

Huckaby, J. L., 1994a, Vapor Sampling System (VSS) and In Situ Sampling (ISS) Method Comparison, WHC-SD-WM-RPT-101 Rev. 0, Westinghouse Hanford Company, Richland, Washington.

Huckaby, J. L., 1994b, Tank 241-C-103 Headspace Flammability, WHC-EP-0734 Rev. 1, Westinghouse Hanford Company, Richland, Washington.

Huckaby, J. L., H. Babad, and D. R. Bratzel, 1995, Headspace Gas and Vapor Characterization Summary for the 43 Vapor Program Suspect Tanks, WHC-SD-WM-ER-514 Rev. 0, Westinghouse Hanford Company, Richland, Washington.

Huckaby, J. L., and D. R. Bratzel, 1995a, Tank 241-BY-104 Headspace Gas and Vapor Characterization Results for Samples Collected in April 1994 and June 1994, WHC-SD-WM-ER-418, Rev. 1, Westinghouse Hanford Company, Richland, Washington.

Huckaby, J. L., and D. R. Bratzel, 1995b, Tank 241-BY-106 Headspace Gas and Vapor Characterization Results for Samples Collected in May 1994 and July 1994, WHC-SD-WM-ER-420, Rev. 1, Westinghouse Hanford Company, Richland, Washington 
Huckaby, J. L., and M. S. Story, 1994, Vapor Characterization of Tank 241-C-103, WHC-EP-0780 Rev. 0, Westinghouse Hanford Company, Richland, Washington.

Jenkins, R. A, A. B. Dindal, C. E. Higgins, C. Y. Ma, and J. T. Skeen, 1994, Analaysis of Tank 241-BY-105 Headspace Components, Oak Ridge National Laboratory, Oak Ridge, Tennessee.

Jenkins, R. A., 1995, Untitled, (Letter 090195A to D. Bratzel, September 1), Oak Ridge National Laboratory, Oak Ridge, Tennessee

Jenkins, R. A, A. B. Dindal, C. Y. Ma, M. A. Palausky, J. T. Skeen, and C. K. Bayne, 1995a, Analysis of Tank 241-TY-103 Headspace Components, ORNL-CASD-FR-241TY103.95 Rev. 0, Oak Ridge National Laboratory, Oak Ridge, Tennessee

Jenkins, R. A, A. B. Dindal, C. Y. Ma, M. A. Palausky, J. T. Skeen, and C. K. Bayne, 1995, Analysis of Tank 241-TY-104 Headspace Components, ORNL-CASD-FR-241TY104.95 Rev. 1, Oak Ridge National Laboratory, Oak Ridge, Tennessee.

Keller, K. K., 1994, Quality Assurance Project Plan for Tank Vapor Characterization, WHC-SD-WM-QAPP. 013 Rev. 2, Westinghouse Hanford Company, Richland, Washington.

Ligotke, M. W., 1995, PNL Vapor Project Analytical Holding Times, (Letter to D. R. Bratzel, September 23 ,1995) Pacific Northwest Laboratory, Richland, Washington.

Mahium, D. D., J. Y. Young, and R. E. Weller, 1994, Toxicologic Evaluation of Analytes from Tank 231-C103, PNL-10189, Pacific Northwest Laboratory, Richland, Washington.

MoVeety, B. D., K. H. Pool, M. W. Ligotke, T. W. Clauss, R. B. Lucke, A. K.Sharma, M. McCulloch, J. S. Fruchter, and S. C. Goheen, 1995a, Vapor Space Characterization of Waste Tank 241-BY-105 (in Situ): Results from Samples Collecfed on 5/9/94, PNL-10282 UC-606, Pacific Northwest Laboratory, Richland, Washington.

McVeety, B. D., T. W. Clauss, M. W. Ligotke, K. H. Pool, R. B. Lucke, G. S. Kinger, J. S. Young, M. McCulloch, J. S. Fruchter, and S. C. Goheen, 1995b, Vapor Space Characterization of Waste Tank 241-BY-108: Results from Samples Collected on 10/27/94, PNL-10495 UC-606, Pacific Northwest Laboratory, Richland, Washington.

Meacham, J. E., H. Babad, R. J. Cash, G. T. Dukelow, S. J. Eberlein, D. W. Hamilton, G. D. Johnson, J. W. Osborne, M. A. Payne, D. J. Sherwood, D. A. Turner, and J. L. Huckaby, 1995, Approach for Tank Safety Characterization of Hanford Site Waste, WHC-EP-0843 Rev. 0, UC-2070, Westinghouse Hanford Company, Richland, Washington.

NFPA 1992, Standard on Explosion Prevention Systems, NFPA 69, National Fire Protection Association, Quincy, Massachusetts.

Osborne, J. W., and J. L. Huckaby, 1994, Program Plan for the Resolution of Tank Vapor issues, WHC-EP0562 Rev. 1, Westinghouse Hanford Company, Richland, Washington.

Osborne, J. W., J. L. Huckaby, T. P. Rudolph, E. R. Hewitt, D. D. Mahlum, J. Y. Young, C. M. Anderson, 1994, Data Quality Objectives for Generic In-Tank Health and Safety Issue Resolution, WHC-SDWM-DQO-002, Westinghouse Hanford Company, Richland, Washington. 


\section{WHC-SD-WM-ER-419 REV. 2}

Pingel, L. A., 1994, Results from the In-Situ Vapor Sampling of Waste Tank BY-105, (Internal memorandum 8E920-SAS94-091 to J. L. Huckaby, May 26), Westinghouse Hanford Company, Richland, Washington.

Pool, K. H, M. W. Ligotke, T. W. Clauss, R. B. Lucke, B. D. McVeety, M. McCulloch, J. S. Fruchter, and S. C. Goheen, 1995, Vapor Space Characterization of Waste Tank 241-BY-105: Results from Samples Collected on 7/7/94, PNL-10256 UC-606, Pacific Northwest Laboratory, Richland, Washington.

Rasmussen, R. A., 1994a, Air Samples Collected at Waste Tanks: BY-103, BY-104, BY-105, BY-106, BY111 by Westinghouse Hanford in 6-L SS SUMMA@ Canisters, Oregon Graduate Institute of Science and Technology, Beaverton, Oregon.

Rasmussen, R. A., 1994b, Air Samples Collected at Waste Tank 241-BY-105 on July 7, 1994 by Westinghouse Hanford in 6-L SS SUMMAB Canisters, Oregon Graduate Institute of Science and Technology, Beaverton, Oregon.

WHC 1995a, Operating Specifications for Watchlist Tanks, OSD-T-151-00030, Rev. B-9, Westinghouse Hanford Company, Richland, Washington

WHC 1995b, Vapor and Gas Sampling of Single-Shell Tank 241-BY-105 Using the Vapor Sampling System, WHC-SD-WM-RPT-108, Westinghouse Hanford Company, Richland, Washington. 
WHC-SD-WM-ER-419 REV. 2

Table 2-1

Tank BY-105 Gas and Vapor Sample Type and Number for the July 1994 VSS Event

\begin{tabular}{|c|c|c|c|c|}
\hline Laboratory & Sampling Device & $\begin{array}{c}\text { Nominal Sample } \\
\text { Volume (L) }\end{array}$ & Target Analytes & Number of Samples \\
\hline $\begin{array}{l}\text { Oak Ridge National } \\
\text { Laboratories }\end{array}$ & Triple Sorbent Trap & 4.0 & Organic vapors & $\begin{array}{l}4 \text { tank air samples } \\
+2 \text { trip blanks }\end{array}$ \\
\hline $\begin{array}{l}\text { Oregon Graduate Institute of } \\
\text { Science and Technology }\end{array}$ & SUMMA ${ }^{T M}$ canister & 6.0 & $\begin{array}{l}\text { Hydrogen, } \\
\text { Nitrous Oxide, Carbon } \\
\text { Dioxide, Carbon Monoxide }\end{array}$ & 3 tank air samples \\
\hline \multirow[t]{5}{*}{$\begin{array}{l}\text { Pacific Northwest } \\
\text { Laboratories }\end{array}$} & Acidified Carbon Sorbent Trap & 3.0 & Ammonia & $\begin{array}{l}5 \text { tank air samples } \\
+2 \text { trip blanks }\end{array}$ \\
\hline & Triethanolamine Sorbent Trap & 3.0 & Nitrogen Dioxide & $\begin{array}{l}10 \text { tank air samples } \\
+2 \text { trip blanks }\end{array}$ \\
\hline & $\begin{array}{l}\text { Oxidation bed + } \\
\text { Triethanolamine Sorbent Trap }\end{array}$ & 3.0 & Nitric Oxide & $\begin{array}{l}10 \text { tank air samples } \\
+2 \text { trip blanks }\end{array}$ \\
\hline & Sifica Gel Sorbent Trap & 3.0 & Water vapor & $\begin{array}{l}10 \text { tank air samples } \\
+2 \text { trip blanks }\end{array}$ \\
\hline & SUMMA ${ }^{\mathrm{TM}}$ canister & 6.0 & Organic vapors & $\begin{array}{l}3 \text { tank air samples } \\
+2 \text { ambjent air samples }\end{array}$ \\
\hline WHC 222-S Laboratory & Silica Gel Sorbent Trap & 2.0 & $\begin{array}{l}\text { Tritium-Substituted Water } \\
\text { Vapor }\end{array}$ & 1 tank air sample \\
\hline
\end{tabular}




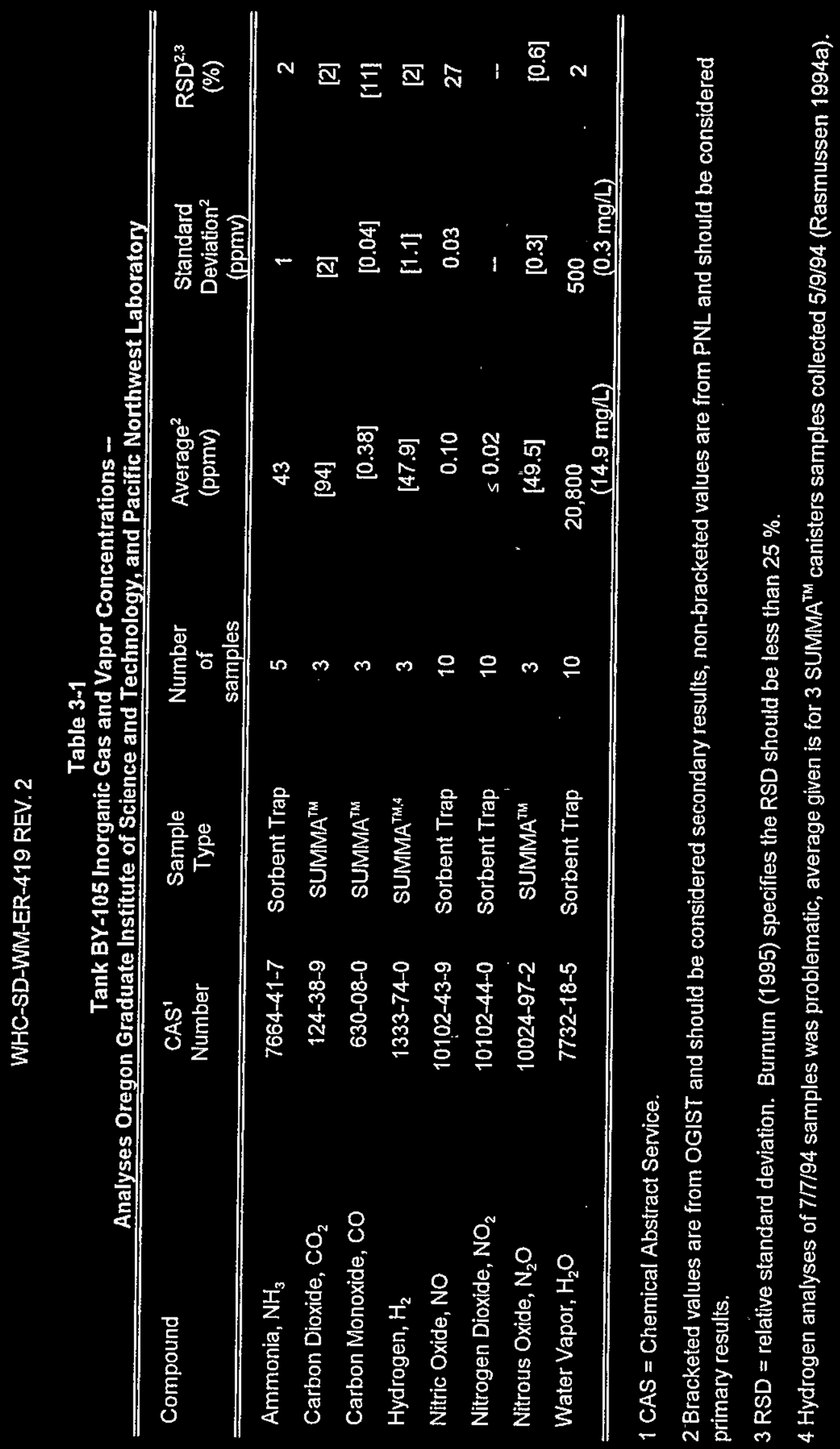


Table 3-2

Comparison of Tank BY-104, BY-105, and BY-106 Headspace Constituents Inorganic Analyses by Oregon Graduate Institute of Science and Technology, and Organic Analyses by Oak Ridge National Laboratory ${ }^{4}$

\begin{tabular}{|c|c|c|c|}
\hline Tank: & $B Y-104^{2}$ & $B Y-105$ & $B Y-106^{3}$ \\
\hline Date sampled, (mo/day/yr) & $6 / 24 / 94$ & $7 / 7 / 94$ & $7 / 8 / 94$ \\
\hline Headspace temperature, $\left({ }^{\circ} \mathrm{C}\right)$ & 26 & 26 & 27 \\
\hline Ammonia, (ppmv) & 248 & 43 & 74 \\
\hline Hydrogen, (ppmv) & [295] & [47.9] & [45.5] \\
\hline Carbon dioxide, (ppmv) & [10.5] & [94] & [47.6] \\
\hline Carbon monoxide, (ppmv) & {$[1.0]$} & {$[0.38]$} & {$[0.45]$} \\
\hline Nitric oxide, (ppmv) & 0.29 & 0.10 & 0.13 \\
\hline Nitrogen dioxide, (ppmv) & $=0.07$ & $\leq 0.02$ & 0.05 \\
\hline Nitrous oxide, (ppmv) & [201] & {$[49.5]$} & [70.6] \\
\hline Water vapor, $\left(\mathrm{mg} / \mathrm{m}^{3}\right)$ & 14.1 & 14.9 & 14.7 \\
\hline Water vapor, (\% relative humidity) & 58 & 76 & 57 \\
\hline Ethanenitrile (acetonitrile), (ppmv) & $(0.33)$ & $(0.081)$ & $(0.12)$ \\
\hline Propanone (acetone), (ppmv) & $(1.2)$ & $(0.25)$ & $(0.37)$ \\
\hline 1-Butanol, (ppmv) & $(1.0)$ & $(0.70)$ & $(0.34)$ \\
\hline n-Dodecane, (ppmv) & $(0.058)$ & $(0.0081)$ & $(0.0065)$ \\
\hline n-Tridecane, (ppmv) & $(0.084)$ & $(0.010)$ & $(0.0069)$ \\
\hline Total nonmethane organic carbon, $\left(\mathrm{mg} / \mathrm{m}^{3}\right)$ & {$[60.8]$} & {$[12.7]$} & [9.9] \\
\hline
\end{tabular}

1 Where PNL inorganic gas or vapor data was unavailable, OGIST results are given. OGIST results are in brackets to indicate the data should be considered secondary results. Organic vapor results are from ORNL, with non-quantitative values in parentheses and quantitative values not in parentheses.

2 Data are from Huckaby and Bratzel 1995a.

3 Data are from Huckaby and Bratzel 1995b. 
WHC-SD-WM-ER-419 REV. 2

Table 4-1

Tank BY-105 Quantitatively Measured Organic Compounds in SUMMA ${ }^{\text {TM }}$ Samples Analyses by Pacific Northwest Laboratory

\begin{tabular}{|c|c|c|c|c|c|}
\hline$\underset{\#}{C \text { Cmpd }}$ & Compound & $\begin{array}{l}\text { CAS }^{1} \\
\text { Numb } \\
\text { er }\end{array}$ & $\begin{array}{l}\text { Average }^{2} \\
\text { (ppmv) }\end{array}$ & $\begin{array}{l}\text { Standard } \\
\text { Deviation } \\
\text { (ppmv) }\end{array}$ & $\begin{array}{l}\mathrm{RSD}^{3} \\
(\%)\end{array}$ \\
\hline 1 & Methane ${ }^{4}$ & $\begin{array}{r}74-82- \\
8\end{array}$ & [3.8] & {$[<0.1]$} & {$[<3]$} \\
\hline 2 & Dichlorodifluoromethane & $\begin{array}{r}75-71- \\
8\end{array}$ & $0.002^{5}$ & - & - \\
\hline 3 & Trichlorofluoromethane & $\begin{array}{r}75-69- \\
4\end{array}$ & 0.044 & 0.006 & 13 \\
\hline 4 & Toluene & $\begin{array}{r}108-8 \\
8-3\end{array}$ & 0.0024 & 0.0002 & 9 \\
\hline 5 & $\begin{array}{l}\text { 1,3-Dimethylbenzene }(m-x y l e n e) \\
\text { 1,4-Dimethylbenzene }(p-x y l e n e)^{6}\end{array}$ & $\begin{array}{l}108- \\
38-3 \\
106- \\
42-3\end{array}$ & 0.0023 & 0.0001 & 3 \\
\hline
\end{tabular}

$1 \mathrm{CAS}=$ Chemical Abstract Service.

2 Average of 3 samples.

3 RSD = relative standard deviation. Burnum (1995) specifies the RSD should be less than $25 \%$.

4 Methane analyses were performed by OGIST and should be considered a secondary result (Ramussen 1994a).

5 Average of 2 samples, other sample result $<0.002$ ppmv.

$6 \mathrm{~m}$-xylene and $\mathrm{p}$-xylene coelute and the reported value represents the sum of their concentrations. 
WHC-SD-WM-ER-419 REV. 2

Table 4-2

Tank BY-105 Quantitatively Measured Organic Compound Average Concentrations Analyses by Oak Ridge National Laboratory ${ }^{\prime}$

\begin{tabular}{clcccc}
\hline $\begin{array}{c}\text { Cmpd } \\
\#\end{array}$ & Compound & $\begin{array}{c}\text { CAS }^{2} \\
\text { Number }\end{array}$ & $\begin{array}{c}\text { Average } \\
\text { (ppmv) }\end{array}$ & $\begin{array}{c}\text { Standard } \\
\text { Deviation } \\
\text { (ppmv) }\end{array}$ & $\begin{array}{c}\text { RSD }^{4} \\
(\%)\end{array}$ \\
\hline \hline 1 & $\begin{array}{l}\text { Dichloromethane (methylene } \\
\text { chloride) }\end{array}$ & $75-09-2$ & 0.0052 & 0.0010 & 19 \\
2 & Benzene & $71-43-2$ & 0.0069 & 0.0007 & 11 \\
3 & 2-Pentanone & $107-87-9$ & 0.012 & 0.002 & 14 \\
4 & Toluene & $108-88-3$ & 0.0086 & 0.0011 & 13 \\
5 & 2-Hexanone & $591-78-6$ & 0.0054 & 0.0007 & 12 \\
6 & 2-Heptanone & $110-43-0$ & 0.0044 & 0.0006 & 13 \\
7 & n-Nonane & $111-84-2$ & 0.0060 & 0.0006 & 10 \\
\hline \hline
\end{tabular}

1 Results in this table are quantitative (as defined in Section 4.1).

$2 \mathrm{CAS}=$ Chemical Abstract Service .

3 Average of 4, 4-L. TST samples.

4 RSD = relative standard deviation. Burnum (1995) specifies the RSD should be less than $25 \%$. 
Table 4-3

Tank BY-105 Positively Identified Organic Compounds in TST Samples Analyses by Oak Ridge National Laboratory

\begin{tabular}{clcccc}
\hline $\begin{array}{c}\text { Cmpd } \\
\#\end{array}$ & Compound & $\begin{array}{c}\text { CAS }^{2} \\
\text { Number }\end{array}$ & $\begin{array}{c}\text { Average } \\
\text { (ppmv) }\end{array}$ & $\begin{array}{c}\text { Standard } \\
\text { Deviation } \\
\text { (ppmv) }\end{array}$ & $\begin{array}{c}\mathbf{R S O D}^{4} \\
(\%)\end{array}$ \\
\hline \hline 1 & Ethanenitrile (acetonitrile) & $75-05-8$ & 0.081 & 0.011 & 14 \\
2 & Propanone (acetone) & $67-64-1$ & 0.25 & 0.02 & 7 \\
3 & Propanenitrile & $107-12-0$ & 0.0017 & 0.0004 & 22 \\
4 & n-Hexane & $110-54-3$ & 0.086 & 0.009 & 10 \\
5 & 1-Butanol & $71-36-3$ & 0.70 & 0.11 & 16 \\
6 & n-Butanenitrile & $109-74-0$ & 0.0010 & 0.0001 & 12 \\
7 & n-Heptane & $142-82-5$ & 0.039 & 0.003 & 8 \\
8 & n-Pentanenitrile & $110-59-8$ & 0.00079 & 0.00008 & 10 \\
9 & n-Octane & $111-65-9$ & 0.015 & 0.001 & 8 \\
10 & n-Hexanenitrile & $628-73-9$ & 0.00085 & 0.00016 & 19 \\
11 & n-Heptanenitrile & $629-08-3$ & 0.00049 & 0.00004 & 7 \\
12 & 2-Octanone & $111-13-7$ & 0.0010 & 0.0002 & 19 \\
13 & n-Octanenitrile & $124-12-9$ & 0.00026 & 0.00002 & 7 \\
14 & n-Nonanenitrile & $2243-27-8$ & 0.00031 & 0.00004 & 14 \\
15 & n-Dodecane & $112-40-3$ & 0.0081 & 0.0008 & 10 \\
16 & n-Tridecane & $629-50-5$ & 0.010 & 0.002 & 15 \\
17 & Tributyl phosphate & $126-73-8$ & 0.00017 & 0.00013 & 76 \\
18 & Dibutyl butylphosphonate & $75-46-4$ & 0.000025 & 0.000013 & 52 \\
\hline \hline
\end{tabular}

1 Results in this table are not quantitative (as defined in Section 4.1) because measured values in at least 1 of the samples are outside instrument calibration limits.

$2 \mathrm{CAS}=$ Chemical Abstract Service.

3 Average of 4, 4-L TST samples.

$4 \mathrm{RSD}=$ relative standard deviation. Burnum (1995) specifies the RSD should be less than $25 \%$. 
WHC-SD-WM-ER-419 REV. 2

Table 4-4

Tank BY-105 Positively Identified Compounds in TST Samples

for which Practical Holding Times were Exceeded -Analyses by Oak Ridge National Laboratory ${ }^{4}$

\begin{tabular}{|c|c|c|c|c|c|}
\hline$\underset{\#}{\text { Cmpd }}$ & Compound & $\begin{array}{c}\mathrm{CAS}^{2} \\
\text { Number }\end{array}$ & $\begin{array}{c}\text { Average }^{3} \\
\text { (ppmin) }\end{array}$ & $\begin{array}{c}\text { Standard } \\
\text { Deviation } \\
\text { (ppmv) }\end{array}$ & $\begin{array}{c}\mathrm{RSD} \\
(\%)\end{array}$ \\
\hline 1 & Butanal $^{5}$ & 123-72-8 & 0.047 & 0.008 & 16 \\
\hline
\end{tabular}

1 Practical holding times are defined and discussed in Section 4.1.

$2 \mathrm{CAS}=$ Chemical Abstract Service.

3 Average of 4,4-L TST samples.

4 RSD = relative standard deviation. Burnum (1995) specifies the RSD should be less than $25 \%$.

5 The concentration of this analyte was not quantitatively measured (as defined in Section 4.1), because the measured concentration was outside of the instrumental calibration limits. 
WHC-SD-WM-ER-419 REV. 2

Table 4-5

Tank BY-105 Comparison of Organic Compounds in TST and SUMMA ${ }^{\mathrm{TM}}$ Samples Analyses by Pacific Northwest Laboratory and Oak Ridge National Laboratory

\begin{tabular}{clcccc}
\hline Cmpd\#\# & Compound & $\begin{array}{c}\text { CAS }^{1} \\
\text { Number }\end{array}$ & $\begin{array}{c}\text { TST } \\
\text { Average } \\
(\text { ppmv) }\end{array}$ & $\begin{array}{c}\text { SUMMA } \\
\text { Average }^{3} \\
\text { (ppmv) }\end{array}$ & $\begin{array}{c}\text { PRD }^{4} \\
(\%)\end{array}$ \\
\hline \hline 1 & $\begin{array}{l}\text { Dichloromethane } \\
\text { (methylene chloride) }\end{array}$ & $75-09-2$ & 0.0052 & $<0.002$ & $>89$ \\
2 & Benzene & $71-43-2$ & 0.0069 & $<0.002$ & $>110$ \\
3 & Toluene & $108-88-3$ & 0.0086 & 0.0024 & 113 \\
\hline \hline
\end{tabular}

$1 \mathrm{CAS}=$ Chemical Abstract Service.

2 Average of 4, 4-L TST samples analyses.

3 Average of 3 samples analyses.

$4 \mathrm{PRD}=$ percent relative difference. Keller (1994) requires the PRD to be less than $20 \%$. 
Table 4-6

Tank BY-105 Tentatively ldentified Organic Compounds in SUMMA'M Samples Analyses by Pacific Northwest Laboratory

\begin{tabular}{|c|c|c|c|c|}
\hline Cmpd & Compound & $\begin{array}{c}\text { CAS }^{1} \\
\text { Number }\end{array}$ & $\begin{array}{l}\text { Average }^{2} \\
\left(\mathrm{mg} / \mathrm{m}^{3}\right)\end{array}$ & $\begin{array}{c}\text { Standard }{ }^{3} \\
\text { Deviation } \\
\left(\mathrm{mg} / \mathrm{m}^{3}\right)\end{array}$ \\
\hline 1 & Propene & $115-07-1$ & 0.96 & 0.19 \\
\hline 2 & Propane & $74-98-6$ & 0.28 & 0.04 \\
\hline 3 & Cyclopropane $^{4}$ & $75-19-4$ & 0.07 & 0.01 \\
\hline 4 & 2-Methylpropane & $75-28-5$ & 0.16 & 0.04 \\
\hline 5 & 2-Methylpropene & $115-11-7$ & 0.34 & 0.07 \\
\hline 6 & n-Butane & $106-97-8$ & 0.25 & 0.05 \\
\hline 7 & C4 Alkene & & 0.06 & 0.01 \\
\hline 8 & 2-Methyi-1-butene ${ }^{5}$ & $563-46-2$ & 0.05 & - \\
\hline 9 & Propanone (acetone) & $67-64-1$ & 0.16 & 0.04 \\
\hline 10 & 2-Methylbutane & $78-78-4$ & 0.09 & 0.02 \\
\hline 11 & 2-Pentene & $109-68-2$ & 0.12 & 0.02 \\
\hline 12 & C5 Alkane & & 0.19 & 0.04 \\
\hline 13 & 2-Methylpentane & $107-83-5$ & 0.47 & 0.07 \\
\hline 14 & 2-Butanone & $78-93-3$ & 0.07 & 0.01 \\
\hline 15 & 3-Methylpentane & $96-14-0$ & 0.09 & 0.01 \\
\hline 16 & 1.Hexene & $107-01-7$ & 0.14 & 0.02 \\
\hline 17 & $\mathrm{n}$-Hexane (coeluent with an internal standard) & $110-54-3$ & 0.34 & 0.06 \\
\hline 18 & Unknown & & 0.12 & 0.02 \\
\hline 19 & C6 Alkene ${ }^{4}$ & & 0.06 & 0.01 \\
\hline 20 & 1-Butanol & $71-36-3$ & 0.53 & 0.08 \\
\hline 21 & C7 Alkane & & 0.07 & 0.01 \\
\hline 22 & C7 Alkane & & 0.14 & 0.01 \\
\hline 23 & 1-Heptene & $592-76-7$ & 0.06 & 0.01 \\
\hline 24 & n-Heptane & $142-82-5$ & 0.22 & 0.03 \\
\hline 25 & 2-Methylheptane & $592-27-8$ & 0.08 & 0.01 \\
\hline 26 & 2,4-Dimethylhexane & $589-43-5$ & 0.08 & 0.01 \\
\hline 27 & Siloxane ${ }^{4}$ & & 0.14 & - \\
\hline 28 & 2-Butoxyethanol ${ }^{3}$ & $111-76-2$ & 0.06 & 0.01 \\
\hline
\end{tabular}


WHC-SD-WM-ER-419 REV. 2

\begin{tabular}{clccc}
\hline \hline $\begin{array}{c}\text { Cmpd } \\
\#\end{array}$ & Compound & $\begin{array}{c}\text { CAS }^{1} \\
\text { Number }\end{array}$ & $\begin{array}{c}\text { Average } \\
\left(\mathrm{mg} / \mathrm{m}^{3}\right)\end{array}$ & $\begin{array}{c}\text { Standard } \\
\text { Deviation } \\
\left(\mathrm{mg} / \mathrm{m}^{3}\right)\end{array}$ \\
\hline \hline 29 & Siloxane $^{5}$ & & 0.07 & - \\
30 & n-Dodecane & $112-70-3$ & 0.09 & 0.01 \\
31 & C13 Alkane & & 0.07 & 0.01 \\
32 & C13 Alkane & & 0.09 & 0.02 \\
33 & n-Tridecane & $629-50-5$ & 0.14 & 0.03 \\
34 & C14 Alkane & & 0.12 & 0.02 \\
35 & n-Tetradecane & $629-59-4$ & 0.13 & 0.03 \\
36 & Unknown & & 0.08 & 0.02 \\
37 & Unknown & & 0.05 & - \\
\hline \hline Sum of tentatively identified compounds: & & 5.96 & \\
\hline \hline
\end{tabular}

1. $C A S=$ Chemical Abstract Service.

2 Average of 3 samples, values listed are estimates.

3 When the analyte was detected in only 2 samples, the entry is the relative difference (i.e., their difference divided by 2 ), values listed are estimates.

4. Detected in only 2 samples.

5. Detected in only 1 sample. 
Table 4-7

Tank BY-105 Tentatively Identified Organic Compounds in TST Samples in Order of Chromatographic Elution--

Analyses Conducted by Oak Ridge National Laboratory

\begin{tabular}{|c|c|c|c|c|}
\hline$\underset{\#}{\text { Cmpd }}$ & Compound & $\begin{array}{c}\text { CAS }^{1} \\
\text { Number }\end{array}$ & $\begin{array}{l}\text { Average }^{2} \\
\left(\mathrm{mg} / \mathrm{m}^{3}\right)\end{array}$ & $\begin{array}{l}\text { Standard } \\
\text { Deviation } \\
\left(\mathrm{mg} / \mathrm{m}^{3}\right)\end{array}$ \\
\hline 1 & 1-Butene or C4-alkene & $106-98-9$ & 0.57 & 0.05 \\
\hline 2 & Butane & $106-97-8$ & 0.47 & 0.05 \\
\hline 3 & 1-Propene,2-methyl or C4-alkene & $115-11-7$ & 0.079 & 0.006 \\
\hline 4 & 1-Propene,2-methyl- or C4 alkene & $115-11-7$ & 0.073 & 0.050 \\
\hline 5 & 1-Propene,2-methyl or C4-alkene & $115-11-7$ & 0.073 & 0.005 \\
\hline 6 & 1-8utene,3-methyl- & $563-45-1$ & 0.068 & 0.008 \\
\hline 7 & Methane, oxybis (methyl ether) & $115-10-6$ & 0.027 & 0.008 \\
\hline 8 & C5-alkane & & 0.21 & 0.14 \\
\hline 9 & Methane, trichlorofluoro- & $75-69-4$ & 0.14 & 0.03 \\
\hline 10 & 2.Pentene, $(Z)$ & $627-20-3$ & 0.0053 & 0.0106 \\
\hline 11 & 1-Pentene & $109-67-1$ & 0.38 & 0.05 \\
\hline 12 & Furan & $110-00-9$ & 0.039 & 0.028 \\
\hline 13 & C5-alkene and C5-alkyne & & 0.20 & 0.03 \\
\hline 14 & 2-Pentene, (Z) & $627-20-3$ & 0.044 & 0.008 \\
\hline 15 & Cyclopropane, ethyl- & $1191-96-4$ & 0.055 & 0.010 \\
\hline 16 & Cyclopropane, 1,1-dimethyl- & $1630-94-0$ & 0.029 & 0.006 \\
\hline 17 & 1-Pentyne and C5-alkene & & 0.013 & 0.009 \\
\hline 18 & 1,2-Pentadiene & $591-95-7$ & 0.032 & 0.007 \\
\hline 19 & 1,3-Butadiene, 2-methyl- & $78-79-5$ & 0.0043 & 0.0087 \\
\hline 20 & 1-Pentene, 4-methyl- & $691-37-2$ & 0.15 & 0.01 \\
\hline 21 & Cyclopentane & $287-92-3$ & 0.052 & 0.013 \\
\hline 22 & Pentane, 2-methyl- & $107-83-5$ & 0.69 & 0.07 \\
\hline 23 & C6-alkene & & 0.030 & 0.008 \\
\hline 24 & Furan, 2,5-dihydro- & $1708-29-8$ & 0.022 & 0.004 \\
\hline 25 & 1-Hexene & $592-41-6$ & 0.0078 & 0.0090 \\
\hline 26 & c6-alkene & & 0.0032 & 0.0064 \\
\hline 27 & Pentane, 3-methyl- & $96-14-0$ & 0.14 & 0.02 \\
\hline
\end{tabular}


WHC-SD-WM-ER-419 REV. 2

\begin{tabular}{|c|c|c|c|c|}
\hline$\underset{\#}{\text { Cmpd }}$ & Compound & $\begin{array}{c}\mathrm{CAS}^{1} \\
\text { Number }\end{array}$ & $\begin{array}{l}\text { Average } 2 \\
\left(\mathrm{mg} / \mathrm{m}^{3}\right)\end{array}$ & $\begin{array}{l}\text { Standard } \\
\text { Deviation } \\
\left(\mathrm{mg} / \mathrm{m}^{3}\right)\end{array}$ \\
\hline 28 & 1-Pentene, 2-methyl- & $763-29-1$ & 0.058 & 0.039 \\
\hline 29 & c6-alkene & & 0.21 & 0.03 \\
\hline 30 & 3-Buten-2-one & $78-94-4$ & 0.021 & 0.001 \\
\hline 31 & 2-Butanone & $78-93-3$ & 0.17 & 0.03 \\
\hline 32 & 3-Hexene, (Z) & $7642-09-3$ & 0.019 & 0.004 \\
\hline 33 & 2-Hexene, (Z) & $7688-21-3$ & 0.038 & 0.006 \\
\hline 34 & 1-Butene, 2,3-dimethyl- & $563-78-0$ & 0.026 & 0.006 \\
\hline 35 & Cyclopropane, 1,2-dimethyl-3-methylene & $4866-55-1$ & 0.020 & 0.004 \\
\hline 36 & Cyclopropane, propyl- & $2415-72-7$ & 0.035 & 0.004 \\
\hline 37 & C6-alkene and others & & 0.025 & 0.003 \\
\hline 38 & Cyclopropane, (1-methylethyl)- & $3638-35-5$ & 0.081 & 0.013 \\
\hline 39 & 2-Propanol & $67-63-0$ & 0.30 & 0.05 \\
\hline 40 & Furan, tetrahydro- & $109-99-9$ & 0.25 & 0.03 \\
\hline 41 & 1,3-Pentadiene, 2-methyl- & $1118-58-7$ & 0.047 & 0.012 \\
\hline 42 & 1,4-Hexadiene & $592-45-0$ & 0.033 & 0.007 \\
\hline 43 & Cyclopropane, butyl- & $930-57-4$ & 0.021 & 0.016 \\
\hline 44 & C4-Cyclopropane & & 0.0095 & 0.0189 \\
\hline 45 & 2-Butenal & $4170-30-3$ & 0.040 & 0.008 \\
\hline 46 & 2-Butanone, 3-methyi- & $563-80-4$ & 0.0031 & 0.0063 \\
\hline 47 & Hexane, 2-methyi- & $591-76-4$ & 0.058 & 0.002 \\
\hline 48 & 1,4-Hexadiene & $592-45-0$ & 0.0012 & 0.0023 \\
\hline 49 & 1-Hexene, 3,4-dimethyl- & $16745-94-1$ & 0.0032 & 0.0037 \\
\hline 50 & Cyclohexene & $110-83-8$ & 0.0043 & 0.0051 \\
\hline 51 & Cyclopropane, butyl- & $930-57-4$ & 0.0086 & 0.0016 \\
\hline 52 & Cyclopropane, butyl- & $930-57-4$ & 0.0086 & 0.0005 \\
\hline 53 & Cyclobutane, isopropyl- & $872-56-0$ & 0.014 & 0.001 \\
\hline 54 & Cyclopropane, butyl- & $930-57-4$ & 0.091 & 0.007 \\
\hline 55 & 3-Heptene, (E) & $14686-14-7$ & 0.0043 & 0.0029 \\
\hline 56 & 2-Butanol & $78-92-2$ & 0.0015 & 0.0030 \\
\hline 57 & 2-Heptene & $592-77-8$ & 0.015 & 0.004 \\
\hline
\end{tabular}


WHC-SD-WM-ER-419 REV. 2

\begin{tabular}{|c|c|c|c|c|}
\hline$\underset{\#}{\text { Cmpd }}$ & Compound & $\begin{array}{l}\text { CAS }^{1} \\
\text { Number }\end{array}$ & $\begin{array}{l}\text { Average }^{2} \\
\left(\mathrm{mg} / \mathrm{m}^{3}\right)\end{array}$ & $\begin{array}{c}\text { Standard } \\
\text { Deviation } \\
\left(\mathrm{mg} / \mathrm{m}^{3}\right) \\
\end{array}$ \\
\hline 58 & Pentane, 2,4-dimethyl- & $108-08-7$ & 0.011 & 0.001 \\
\hline 59 & 2-Heptene & $592-77-8$ & 0.0080 & 0.0007 \\
\hline 60 & Cyclohexane, methyl- & $108-87-2$ & 0.050 & 0.003 \\
\hline 61 & c7-alkene & & 0.0011 & 0.0022 \\
\hline 62 & Hexane, 2,4-dimethyl- & $589-43-5$ & 0.0021 & 0.0024 \\
\hline 63 & Cyclopentane, ethyl- & $1640-89-7$ & 0.010 & 0.001 \\
\hline 64 & 2-Pentanol, 2-methyl- & $590-36-3$ & 0.010 & 0.002 \\
\hline 65 & Cyclopentane, 1,2,4-trimethyl- & $4850-28-6$ & 0.0066 & 0.0012 \\
\hline 66 & 2-Pentanone, 4-methyl- & $108-10-1$ & 0.010 & 0.004 \\
\hline 67 & 1-Heptene, 3-methyl- and others & & 0.0010 & 0.0021 \\
\hline 68 & Mixture & & 0.0057 & 0.0005 \\
\hline 69 & c8-alkene & & 0.027 & 0.004 \\
\hline 70 & 1-Octene & $111-66-0$ & 0.0022 & 0.0026 \\
\hline 71 & Hexane, 2,3-dimethyi- & $584-94-1$ & 0.034 & 0.002 \\
\hline 72 & Mixture & & 0.016 & 0.026 \\
\hline 73 & Heptane, 3-methyl- & $589-81-1$ & 0.041 & 0.029 \\
\hline 74 & Cyciohexane, 1,3-dimethyl & $638-04-0$ & 0.013 & 0.003 \\
\hline 75 & $\begin{array}{l}\text { 2,4-Hexadiene, 3-methyl-and } \\
\text { C2-Cyclohexane }\end{array}$ & & 0.0035 & 0.0041 \\
\hline 76 & Unknown & & 0.0012 & 0.0025 \\
\hline 77 & 3-Hexanone & $589-38-8$ & 0.021 & 0.002 \\
\hline 78 & Alkene & & 0.0045 & 0.0053 \\
\hline 79 & C7-Alkene & & 0.0100 & 0.0054 \\
\hline 80 & Ethane, 1,2-dimethoxy- & $110-71-4$ & 0.0030 & 0.0060 \\
\hline 81 & 4-Octene, $(E)$ & $14850-23-8$ & 0.0100 & 0.0025 \\
\hline 82 & Ethene, tetrachloro- & $127-18-4$ & 0.0011 & 0.0021 \\
\hline 83 & Acetic acid, butyl ester & $123-86-4$ & 0.0067 & 0.0016 \\
\hline 84 & Hexamethylcyclotrisiloxane & $541-05-9$ & 0.0078 & 0.0011 \\
\hline 85 & Alkene & & 0.0011 & 0.0021 \\
\hline 86 & Pyridine, 3-methyl- & $108-99-6$ & 0.0039 & 0.0044 \\
\hline
\end{tabular}




\begin{tabular}{|c|c|c|c|c|}
\hline$\underset{\#}{\text { Cmpd }}$ & Compound & $\begin{array}{c}\mathrm{CAS}^{1} \\
\text { Number }\end{array}$ & $\begin{array}{l}\text { Average }{ }^{2} \\
\left(\mathrm{mg} / \mathrm{m}^{3}\right)\end{array}$ & $\begin{array}{c}\text { Standard } \\
\text { Deviation } \\
\left(\mathrm{mg} / \mathrm{m}^{3}\right)\end{array}$ \\
\hline 87 & Heptane, 2,6-dimethyl- & $1072-05-5$ & 0.034 & 0.003 \\
\hline 88 & 4-Heptenal, (Z) & $6728-31-0$ & 0.0078 & 0.0008 \\
\hline 89 & Cyclohexane, ethyl- & $1678-91-7$ & 0.016 & 0.002 \\
\hline 90 & Cyclohexane, 1,1,3-trimethyl- & $3073-66-3$ & 0.022 & 0.002 \\
\hline 91 & Alkanol and alkene & & 0.0091 & 0.0005 \\
\hline 92 & Mixture & & 0.013 & 0.006 \\
\hline 93 & Mixture & & 0.0093 & 0.0045 \\
\hline 94 & Cyclohexàne, 1,3,5-trimethyl- & $1839-63-0$ & 0.0073 & 0.0019 \\
\hline 95 & Heptane, 2,3-dimethyl- & $3074-71-3$ & 0.0088 & 0.0077 \\
\hline 96 & Octane, 4-methyl- & $2216-34-4$ & 0.028 & 0.003 \\
\hline 97 & Octane, 3-methyl- & $2216-33-3$ & 0.036 & 0.019 \\
\hline 98 & 4-Heptanone & $123-19-3$ & 0.016 & 0.006 \\
\hline 99 & Benzene, 1,2-dimethyl- & $95-47-6$ & 0.0079 & 0.0072 \\
\hline 100 & Heptane, 2,5-dimethyl- & $2216-30-0$ & 0.018 & 0.007 \\
\hline 101 & Butane, $1,1^{\prime}$-oxybis- & $142-96-1$ & 0.0083 & 0.0158 \\
\hline 102 & 3-Heptanone & $106-35-4$ & 0.047 & 0.021 \\
\hline 103 & Styrene & $100-42-5$ & 0.0059 & 0.0008 \\
\hline 104 & 3-Heptanol & $589-82-2$ & 0.011 & 0.003 \\
\hline 105 & Heptanal and others & & 0.0092 & 0.0050 \\
\hline 106 & 1-Hexene, 3,5,5-trimethyl- & $4316-65-8$ & 0.0020 & 0.0040 \\
\hline 107 & 1,1,2,3-Tetramethylcyclohexane & $6783-92-2$ & 0.0012 & 0.0028 \\
\hline 108 & $\begin{array}{l}1 \mathrm{R}, 2 \mathrm{~T}, 4 \mathrm{C}, 5 \mathrm{~T}-1,2,4,5-\text { Tetramethylcyclo- } \\
\text { hexane }\end{array}$ & & 0.0013 & 0.0030 \\
\hline 109 & Cyclohexane, 1-ethyl-4-methyl, trans- & $6236-88-0$ & 0.0068 & 0.0008 \\
\hline 110 & 2-Heptanone, 3-methyl- & $2371-19-9$ & 0.0073 & 0.0047 \\
\hline 111 & Mixture & & 0.020 & 0.011 \\
\hline 112 & 2-Heptanol, 2-methyl- and others & & 0.0019 & 0.0102 \\
\hline 113 & Octane, 2,6-dimethyl- & $2051-30-1$ & 0.027 & 0.014 \\
\hline 114 & Cyclohexane, 1-propenyl- & $5364-83-0$ & 0.0030 & 0.0063 \\
\hline 115 & Pyridine, 3,5-dimethyl- and others & & 0.012 & 0.004 \\
\hline
\end{tabular}


WHC-SD-WM-ER-419 REV. 2

\begin{tabular}{|c|c|c|c|c|}
\hline$\underset{\#}{\text { Cmpd }}$ & Compound & $\begin{array}{c}\mathrm{CAS}^{1} \\
\text { Number }\end{array}$ & $\begin{array}{c}\text { Average }^{2} \\
\left(\mathrm{mg} / \mathrm{m}^{3}\right)\end{array}$ & $\begin{array}{l}\text { Standard } \\
\text { Deviation } \\
\left(\mathrm{mg} / \mathrm{m}^{3}\right)\end{array}$ \\
\hline 116 & Heptane, 3-ethyl-2-methyl- & $14676-29-0$ & 0.0071 & 0.0003 \\
\hline 117 & c9-alkene & & 0.0099 & 0.0136 \\
\hline 118 & 2-Heptanone, 6-methyl- & $928-68-7$ & 0.049 & 0.026 \\
\hline 119 & Octane, 3,4-dimethyl- & $15869-92-8$ & 0.0062 & 0.0067 \\
\hline 120 & Benzene, propyl- & $103-65-1$ & 0.0010 & 0.0065 \\
\hline 121 & Nonane, 4-methyl- & $17301-94-9$ & 0.013 & 0.010 \\
\hline 122 & 1,1,2,3-tetramethylcyclohexane & $6783-92-2$ & 0.027 & 0.005 \\
\hline 123 & C3-benzene and alkane & & 0.024 & 0.009 \\
\hline 124 & Octane, 2,3,7-trimethyl- & $62016-34-6$ & 0.016 & 0.006 \\
\hline 125 & Cycloheptane, methoxy and others & & 0.0047 & 0.0037 \\
\hline 126 & Alkyl-cyciohexene & & 0.0017 & 0.0037 \\
\hline 127 & Cyclohexane, 1-methyl-4-(1-methylethy) & $6069-98-3$ & 0.0072 & 0.0017 \\
\hline 128 & C4-Cyclohexane & & 0.0014 & 0.0033 \\
\hline 129 & Cyclohexane, 1-methyl-4-(1-methylethyl) & $6069-98-3$ & 0.0049 & 0.0022 \\
\hline 130 & Phenol & $108-95-2$ & 0.014 & 0.005 \\
\hline 131 & Cyclotetrasiloxane and C4-cyclohexane & & 0.023 & 0.009 \\
\hline 132 & Butanoic acid butyl ester & $109-21-7$ & 0.0066 & 0.0224 \\
\hline 133 & Decane & $124-18-5$ & 0.058 & 0.029 \\
\hline 134 & Cyclopentane, (2-methylbutyl) & $53366-38-4$ & 0.00094 & 0.00266 \\
\hline 135 & Cyciohexane, 1-methyl-3-propyl- & $4291-80-9$ & 0.0062 & 0.0015 \\
\hline 136 & 3-Hexene, 3-ethyl-2,5-dimethyl- & $62338-08-3$ & 0.0039 & 0.0006 \\
\hline 137 & Cyclooctane, 1,5-dimethyl- & $21328-57-4$ & 0.0063 & 0.0012 \\
\hline 138 & 1-Octanol, 2 butyl- and others & & 0.0046 & 0.0004 \\
\hline 139 & 3-Hexene, 2,2,5,5-tetramethyl- and others & & 0.0061 & 0.0160 \\
\hline 140 & Nonane, 2,6-dimethyl- & $17302-28-2$ & 0.042 & 0.022 \\
\hline 141 & Mixture & & 0.0046 & 0.0009 \\
\hline 142 & 1-Hexanol, 2-ethyl- & $104-76-7$ & 0.0071 & 0.0015 \\
\hline 143 & Mixture & & 0.0058 & 0.0045 \\
\hline 144 & C5-Cyclohexane & & 0.016 & 0.003 \\
\hline 145 & C5-Cyclohexane & & 0.0034 & 0.0037 \\
\hline
\end{tabular}




\begin{tabular}{|c|c|c|c|c|}
\hline$\underset{\#}{C \text { Cmpd }}$ & Compound & $\begin{array}{l}\text { CAS }^{1} \\
\text { Number }\end{array}$ & $\begin{array}{l}\text { Average }^{2} \\
\left(\mathrm{mg} / \mathrm{m}^{3}\right)\end{array}$ & $\begin{array}{l}\text { Standard } \\
\text { Deviation } \\
\left(\mathrm{mg} / \mathrm{m}^{3}\right)\end{array}$ \\
\hline 146 & $\begin{array}{l}\text { Cyclopropane, } \\
\text { 1,1,2-trimethyl-3-(2-methylpropyl)- }\end{array}$ & $41977-43-9$ & 0.0081 & 0.0001 \\
\hline 147 & Nonane, 4,5-dimethyl- & $17302-23-7$ & 0.0061 & 0.0054 \\
\hline 148 & 1,1-Dimethyl-2-propylcyclohexane & & 0.019 & 0.007 \\
\hline 149 & Decane, 4-methyl- & $2847-72-5$ & 0.0073 & 0.0049 \\
\hline 150 & Decane, 2-methyl- & $6975-98-0$ & 0.021 & 0.003 \\
\hline 151 & Naphthalene, decahydro, trans- & 493-02-7 & 0.029 & 0.008 \\
\hline 152 & Ethanone, 1-phenyl- & $98-86-2$ & 0.0084 & 0.0021 \\
\hline 153 & Phenol, 3-methyl- & $108-39-4$ & 0.012 & 0.002 \\
\hline 154 & $\begin{array}{l}\text { Cyclohexane, } \\
\text { 1-(cyclohexylmethyl)-4-methyl-, trans- }\end{array}$ & $54823-98-2$ & 0.0080 & 0.0020 \\
\hline 155 & Cyclohexane, 2,4-diethyl-1-methyl- & $61142-70-9$ & 0.0042 & 0.0062 \\
\hline 156 & 5-Undecene & $4941-53-1$ & 0.016 & 0.005 \\
\hline 157 & 2-Nonanone & $821-55-6$ & 0.0047 & 0.0037 \\
\hline 158 & Benzenemethanol, a,a-dimethyl- & $617-94-7$ & 0.0090 & 0.0358 \\
\hline 159 & Undecane & $1120-21-4$ & 0.088 & 0.043 \\
\hline 160 & 5-Undecene & $4941-53-1$ & 0.0034 & 0.0021 \\
\hline 161 & Furan, 3-(1,1-dimethylethyl)2,3-dihydro- & $34314-82-4$ & 0.0038 & 0.0008 \\
\hline 162 & Cyclopropane, 1-butyl-1-methyl-2-propyl- & $41977-34-8$ & 0.0049 & 0.0047 \\
\hline 163 & Undecane, 5-methyl- & $1632-70-8$ & 0.015 & 0.003 \\
\hline 164 & 1-Nonyne & $3452-09-3$ & 0.0091 & 0.0134 \\
\hline 165 & Butanoic acid, 2-hexenyl ester, (E) & $53398-83-7$ & 0.039 & 0.020 \\
\hline 166 & 3-Decyne & $2384-85-2$ & 0.0032 & 0.0025 \\
\hline 167 & 6-Dodecene, (E) & $7206-17-9$ & 0.0091 & 0.0032 \\
\hline 168 & Cyclohexane, pentyl- & $4292-92-6$ & 0.017 & 0.007 \\
\hline 169 & Naphthalene, decahydro-2-methyl- & $2958-76-1$ & 0.032 & 0.014 \\
\hline 170 & 1-Undecene, 4-methyl- & $74630-39-0$ & 0.0039 & 0.0149 \\
\hline 171 & 6-Methylundecane & $17302-33-9$ & 0.036 & 0.010 \\
\hline 172 & Undecane, 4-methyl- & $2980-69-0$ & 0.019 & 0.004 \\
\hline 173 & Undecane, 2-methyl- & $7045-71-8$ & 0.032 & 0.012 \\
\hline 174 & C11-alkene & & 0.010 & 0.002 \\
\hline
\end{tabular}




\begin{tabular}{|c|c|c|c|c|}
\hline$\underset{\#}{\text { Cmpd }}$ & Compound & $\begin{array}{c}\mathrm{CAS}^{1} \\
\text { Number }\end{array}$ & $\begin{array}{l}\text { Average }^{2} \\
\left(\mathrm{mg} / \mathrm{m}^{3}\right)\end{array}$ & $\begin{array}{l}\text { Standard } \\
\text { Deviation } \\
\left(\mathrm{mg} / \mathrm{m}^{3}\right)\end{array}$ \\
\hline 175 & Undecane, 3-methyl- & $1002-43-3$ & 0.014 & 0.005 \\
\hline 176 & C2-decahydronaphthalene & & 0.0026 & 0.0025 \\
\hline 177 & 3-Undecene, 8-methyl- & . & 0.0060 & 0.0031 \\
\hline 178 & Naphthalene, decahydro, 1,5-dimethyl- & $66552-62-3$ & 0.0036 & 0.0045 \\
\hline 179 & Decane, 2,3,6-trimethyl- & $62238-12-4$ & 0.010 & 0.005 \\
\hline 180 & c13-alkene & & 0.0019 & 0.0013 \\
\hline 181 & Cyclohexane, 1-methyi-3-pentyl- & $54411-02-8$ & 0.012 & 0.007 \\
\hline 182 & Cyclohexane, 1-methyl-4-(1-methylbutyl)- & $54411-00-6$ & 0.011 & 0.001 \\
\hline 183 & Undecane, 2,4-dimethyl- and others & & 0.0019 & 0.0022 \\
\hline 184 & Undecane, 2,6-dimethyl- & $17301-23-4$ & 0.066 & 0.003 \\
\hline 185 & Alkenyl-cyclopentane & & 0.0041 & 0.0003 \\
\hline 186 & Nonane, 5-butyl- & $17312-63-9$ & 0.012 & 0.0002 \\
\hline 187 & Undecane, 3-methyl- & $1002-43-3$ & 0.0034 & 0.0004 \\
\hline 188 & $\begin{array}{l}\text { Cyciopentane, } \\
\text { 1,1,3-trimethyl-3-(2-methyl-2-propenyl)- }\end{array}$ & $74421-09-3$ & 0.0091 & 0.0004 \\
\hline 189 & Cyclopentane, 1-pentyl-2-propyl- & $62199-51-3$ & 0.0030 & 0.0004 \\
\hline 190 & Alkene & & 0.00098 & 0.00196 \\
\hline 191 & Cyclohexane, 2-butyl-1,1,3-trimethyl- & $54676-39-0$ & 0.023 & 0.001 \\
\hline 192 & C3-decahydronaphthalene & & 0.0020 & 0.0041 \\
\hline 193 & C3-decahydronaphthalene & & 0.013 & 0.008 \\
\hline 194 & C3-decahydro-naphthalene & & 0.0068 & 0.0079 \\
\hline 195 & Cyclohexane, hexyl- & $4292-75-5$ & 0.016 & 0.006 \\
\hline 196 & Dodecane, 6-methyl- & $6044-71-9$ & 0.0082 & 0.0056 \\
\hline 197 & Undecane, 2,4-dimethyl- & $17312-80-0$ & 0.0064 & 0.0004 \\
\hline 198 & Dodecane, 4-methyl- & $6117-97-1$ & 0.017 & 0.001 \\
\hline 199 & Undecane, 2,10-dimethyl- & $17301-27-8$ & 0.039 & 0.003 \\
\hline 200 & Decane, 2,6,7-trimethyl- & $62108-25-2$ & 0.12 & 0.01 \\
\hline 201 & C7-cyclohexane & & 0.026 & 0.003 \\
\hline 202 & $\begin{array}{l}\text { 2(3H)-Benzofuranone, } \\
\text { 3a,4,5,6-tetrahydro-3a,6,6-trimethyl- }\end{array}$ & $16778-26-0$ & 0.014 & 0.001 \\
\hline 203 & 1-Tridecene & 2437-56-1 & 0.0035 & 0.0003 \\
\hline
\end{tabular}


WHC-SD-WM-ER-419 REV. 2

\begin{tabular}{|c|c|c|c|c|}
\hline Cmpd & Compound & $\begin{array}{c}\mathrm{CAS}^{1} \\
\text { Number }\end{array}$ & $\begin{array}{l}\text { Average }^{2} \\
\left(\mathrm{mg} / \mathrm{m}^{3}\right)\end{array}$ & $\begin{array}{c}\text { Standard } \\
\text { Deviation } \\
\left(\mathrm{mg} / \mathrm{m}^{3}\right)\end{array}$ \\
\hline 204 & 6-Tetradecene, cis & & 0.038 & 0.001 \\
\hline 205 & Phenol, 4-(1,1-dimethylethyl)- and others & & 0.0055 & 0.0005 \\
\hline 206 & Undecane, 2,4-dimethyl- & $17312-80-0$ & 0.0048 & 0.0005 \\
\hline 207 & C14-alkane & & 0.011 & 0.001 \\
\hline 208 & Tridecane, 6-methyl- & $13287-21-3$ & 0.033 & 0.003 \\
\hline 209 & 1-Dodecanol & $112-53-8$ & 0.0011 & 0.0023 \\
\hline 210 & C8-Cyclohexane & & 0.0067 & 0.0002 \\
\hline 211 & C8-Cyclohexane & & 0.0012 & 0.0023 \\
\hline 212 & Mixture & $\cdot$ & 0.0012 & 0.0025 \\
\hline 213 & Mixture & & 0.0084 & 0.0005 \\
\hline 214 & C9-cyclopentane & & 0.0081 & 0.0004 \\
\hline 215 & Tetradecane & $629-59-4$ & 0.017 & 0.001 \\
\hline 216 & Cyclohexane, octyl- & $1795-15-9$ & 0.035 & 0.002 \\
\hline 217 & Tridecane, 4-methyl- & $26730-12-1$ & 0.023 & 0.003 \\
\hline 218 & Tridecane, 2-methyl- & $1560-96-9$ & 0.029 & 0.005 \\
\hline 219 & Alkane & & 0.0044 & 0.0050 \\
\hline 220 & Decane, 2,3,8-trimethyl- & $62238-14-6$ & 0.0024 & 0.0047 \\
\hline 221 & Tridecane, 3-methyl- & $6418-41-3$ & 0.046 & 0.003 \\
\hline 222 & Dodecane, 2,6,10-trimethyl- & $3891-98-3$ & 0.15 & 0.01 \\
\hline 223 & Tetradecane & $629-59-4$ & 0.15 & 0.03 \\
\hline 224 & Tridecane, 4,8-dimethyl- & $55030-62-1$ & 0.029 & 0.001 \\
\hline 225 & $\begin{array}{l}\text { Cyclohexane, } \\
\text { 1,1,3-trimethyl-2-(3-methylpentyl)- }\end{array}$ & $54965-05-8$ & 0.0085 & 0.0024 \\
\hline 226 & Dodecane, 2,6,11-trimethyl- & $31295-56-4$ & 0.019 & 0.0005 \\
\hline 227 & Alkanol & & 0.0061 & 0.0041 \\
\hline 228 & Dodecane, 2,6,11-trimethyl- & $31295-56-4$ & 0.024 & 0.002 \\
\hline 229 & C15-Alkane & & 0.013 & 0.002 \\
\hline 230 & $\begin{array}{l}\text { Dodecane, 2,6,11-trimethyl- or } \\
\text { C15-alkane }\end{array}$ & & 0.028 & 0.004 \\
\hline 231 & Hexadecane & $544-76-3$ & 0.16 & 0.01 \\
\hline 232 & Tetradecane, 3-methyl- & $18435-22-8$ & 0.024 & 0.005 \\
\hline
\end{tabular}




\begin{tabular}{|c|c|c|c|c|}
\hline$\underset{\#}{\text { Cmpd }}$ & Compound & $\begin{array}{c}\text { CAS }^{1} \\
\text { Number }\end{array}$ & $\begin{array}{l}\text { Average }^{2} \\
\left(\mathrm{mg} / \mathrm{m}^{3}\right)\end{array}$ & $\begin{array}{c}\text { Standard } \\
\text { Deviation } \\
\left(\mathrm{mg} / \mathrm{m}^{3}\right)\end{array}$ \\
\hline 233 & Alkane & & 0.0087 & 0.0100 \\
\hline 234 & C16-alkane & & 0.016 & 0.001 \\
\hline 235 & 1-Hexadecene & $629-73-2$ & 0.025 & 0.001 \\
\hline 236 & Pentadecane & $629-62-9$ & 0.14 & 0.03 \\
\hline 237 & 1-Tetradecanol & $112-72-1$ & 0.0019 & 0.0037 \\
\hline 238 & C9-Cyclopentane & & 0.0016 & 0.0032 \\
\hline 239 & C9-Cyclohexane & & 0.012 & 0.001 \\
\hline 240 & C7-Cyclohexane & & 0.0056 & 0.0008 \\
\hline 241 & Tridecane, 5-propyl- & $55045-11-9$ & 0.0023 & 0.0016 \\
\hline 242 & Tetradecane, 2,6,10-trimethyl- & $14905-56-7$ & 0.017 & 0.003 \\
\hline 243 & Tetradecane, 4,11-dimethyl- & $55045-12-0$ & 0.0047 & 0.0055 \\
\hline 244 & Dodecane, 2-methyl-8-propyl- & $55045-07-3$ & 0.014 & 0.004 \\
\hline 245 & Decane, 3-cyclohexyl, 3-cyclohexyl- & $13151-74-1$ & 0.016 & 0.002 \\
\hline 246 & Hexadecane, 2-methyl- & $1560-92-5$ & 0.0066 & 0.0044 \\
\hline 247 & 5-Undecanone, 2-methyl- & $50639-02-6$ & 0.0048 & 0.0034 \\
\hline 248 & Pentadecane & $629-62-9$ & 0.0043 & 0.0028 \\
\hline 249 & Hexadecane & $544-76-3$ & 0.051 & 0.017 \\
\hline 250 & 3-Hexadecene, (Z)- & $34303-81-6$ & 0.0012 & 0.0014 \\
\hline 251 & $\begin{array}{l}\text { Propanoic acid, 2-methyl-,1-(1,1-dimethyl- } \\
\text { ethyl)-2-methyl-1,3-propanediyl ester }\end{array}$ & $74381-40-1$ & 0.026 & 0.017 \\
\hline 252 & 1,2-Benzenedicarboxylic acid, diethyl ester & $84-66-2$ & 0.0095 & 0.0190 \\
\hline 253 & Pentadecane, 2,6,10-trimethyl- & $3892-00-0$ & 0.015 & 0.004 \\
\hline 254 & Cyclohexane, decyl & $1795-16-0$ & 0.0017 & 0.0011 \\
\hline 255 & 5-Undecanone, 2-methyl- & $50639-02-6$ & 0.0021 & 0.0015 \\
\hline 256 & 1-Hexadecene & $629-73-2$ & 0.0047 & 0.0015 \\
\hline 257 & Heptadecane & $629-78-7$ & 0.0073 & 0.0049 \\
\hline 258 & Pentadecane, 2,6,10,14-tetramethyl- & $1921-70-6$ & 0.0076 & 0.0027 \\
\hline 259 & Tetradecanoic acid & $544-63-8$ & 0.0080 & 0.0040 \\
\hline 260 & Octadecane & $593-45-3$ & 0.0011 & 0.0013 \\
\hline 261 & Siloxane & & 0.0011 & 0.0012 \\
\hline
\end{tabular}


WHC-SD-WM-ER-419 REV. 2

\begin{tabular}{clccc}
\hline $\begin{array}{c}\text { Cmpd } \\
\#\end{array}$ & Compound & $\begin{array}{c}\text { CAS } \\
\text { Number }\end{array}$ & $\begin{array}{c}\text { Average } \\
\left(\mathrm{mg} / \mathrm{m}^{3}\right)\end{array}$ & $\begin{array}{c}\text { Standard } \\
\text { Deviation } \\
\left(\mathrm{mg} / \mathrm{m}^{3}\right)\end{array}$ \\
\hline \hline 262 & Benzenesulfonamide, N-butyl- & $3622-84-2$ & 0.029 & 0.007 \\
263 & 2-Pentadecanone, 6,10,14-trimethyl- & $502-69-2$ & 0.0029 & 0.0022 \\
264 & Pentadecanoic acid & $1002-84-2$ & 0.00097 & 0.00193 \\
265 & 1-Hexadecanol & $36653-82-4$ & 0.0024 & 0.0018 \\
266 & Hexanedioic acid, dioctyl ester & $123-79-5$ & 0.0016 & 0.0031 \\
267 & Mixture & & 0.0012 & 0.0025 \\
268 & 2-Heptadecanone & $2922-51-2$ & 0.00042 & 0.00085 \\
269 & 2-Pentadecanone, 6,10,14-trimethyl- & $502-69-2$ & 0.00098 & 0.00113 \\
270 & Hexadecanoic acid & $57-10-3$ & 0.0085 & 0.0058 \\
271 & Hexadecane, 2,6,10,14-tetramethyl- & $638-36-8$ & 0.00055 & 0.00109 \\
272 & Hexadecanoic acid, 1-methylethyl ester & $142-91-6$ & 0.0041 & 0.0029 \\
\hline \hline
\end{tabular}

$1 \mathrm{CAS}=$ Chemical Abstract Service.

2 Average of 4, 4-L. TST samples analyses, values listed are estimates. 
Table 4-8

Tank BY-105 Tentatively ldentified Organic Compounds in TST Samples Sorted Alphanumerically-Analyses Conducted by Oak Ridge National Laboratory

\begin{tabular}{|c|c|c|c|c|}
\hline$\underset{\#}{\text { Cmpd }}$ & Compound & $\begin{array}{c}\text { CAS }^{1} \\
\text { Number }\end{array}$ & $\begin{array}{l}\text { Average }{ }^{2} \\
\left(\mathrm{mg} / \mathrm{m}^{3}\right)\end{array}$ & $\begin{array}{c}\text { Standard } \\
\text { Deviation } \\
\left(\mathrm{mg} / \mathrm{m}^{3}\right)\end{array}$ \\
\hline 1 & 1-Butene or C4-alkene & $106-98-9$ & 0.57 & 0.05 \\
\hline 67 & 1-Heptene, 3-methyl- and others & . & 0.0010 & 0.0021 \\
\hline 3 & 1-Propene,2-methyl or C4-alkene & $115-11-7$ & 0.079 & 0.006 \\
\hline 4 & 1-Propene,2-methyl- or C4 alkene & $115-11-7$ & 0.073 & 0.050 \\
\hline 5 & 1-Propene,2-methyl or C4-alkene & $115-11-7$ & 0.073 & 0.005 \\
\hline 6 & 1-Butene,3-methyl- & $563-45-1$ & 0.068 & 0.008 \\
\hline 164 & 1-Nonyne & $3452-09-3$ & 0.0091 & 0.0134 \\
\hline 49 & 1-Hexene, 3,4-dimethyl- & $16745-94-1$ & 0.0032 & 0.0037 \\
\hline 265 & 1-Hexadecanol & $36653-82-4$ & 0.0024 & 0.0018 \\
\hline 170 & 1-Undecene, 4-methyl- & $74630-39-0$ & 0.0039 & 0.0149 \\
\hline 11 & 1-Pentene & $109-67-1$ & 0.38 & 0.05 \\
\hline 70 & 1-Octene & $111-66-0$ & 0.0022 & 0.0026 \\
\hline 142 & 1-Hexanol, 2-ethyl- & $104-76-7$ & 0.0071 & 0.0015 \\
\hline 203 & 1-Tridecene & $2437-56-1$ & 0.0035 & 0.0003 \\
\hline 256 & 1-Hexadecene & $629-73-2$ & 0.0047 & 0.0015 \\
\hline 235 & 1.Hexadecene & $629-73-2$ & 0.025 & 0.001 \\
\hline 17 & 1-Pentyne and C5-alkene & & 0.013 & 0.009 \\
\hline 34 & 1-Butene, 2,3-dimethyl- & $563-78-0$ & 0.026 & 0.006 \\
\hline 28 & 1-Pentene, 2-methyl- & $763-29-1$ & 0.058 & 0.039 \\
\hline 20 & 1-Pentene, 4-methyl- & $691-37-2$ & 0.15 & 0.01 \\
\hline 209 & 1-Dodecanol & $112-53-8$ & 0.0011 & 0.0023 \\
\hline 138 & 1-Octanol, 2 butyl- and others & & 0.0046 & 0.0004 \\
\hline 106 & 1-Hexene, 3,5,5-trimethyl- & $4316-65-8$ & 0.0020 & 0.0040 \\
\hline 237 & 1-Tetradecanol & $112-72-1$ & 0.0019 & 0.0037 \\
\hline 25 & 1-Hexene & $592-41-6$ & 0.0078 & 0.0090 \\
\hline 148 & 1,1-Dimethyl-2-propylcyclohexane & & 0.019 & 0.007 \\
\hline 252 & 1,2-Benzenedicarboxylic acid, diethyl ester & $84-66-2$ & 0.0095 & 0.0190 \\
\hline
\end{tabular}


WHC-SD-WM-ER-419 REV. 2

\begin{tabular}{|c|c|c|c|c|}
\hline$\underset{\#}{C \text { Cmpd }}$ & Compound & $\begin{array}{l}\text { CAS }^{1} \\
\text { Number }\end{array}$ & $\begin{array}{l}\text { Average } \\
\left(\mathrm{mg} / \mathrm{m}^{3}\right)\end{array}$ & $\begin{array}{c}\text { Standard } \\
\text { Deviation } \\
\left(\mathrm{mg} / \mathrm{m}^{3}\right)\end{array}$ \\
\hline 18 & 1,2-Pentadiene & $591-95-7$ & 0.032 & 0.007 \\
\hline 19 & 1,3-Butadiene, 2-methyl- & $78-79-5$ & 0.0043 & 0.0087 \\
\hline 41 & 1,3-Pentadiene, 2-methyl- & $1118-58-7$ & 0.047 & 0.012 \\
\hline 48 & 1,4-Hexadiene & $592-45-0$ & 0.0012 & 0.0023 \\
\hline 42 & 1,4-Hexadiene & $592-45-0$ & 0.033 & 0.007 \\
\hline 122 & 1,1,2,3-tetramethylcyclohexane & $6783-92-2$ & 0.027 & 0.005 \\
\hline 107 & 1,1,2,3-Tetramethylcyclohexane & $6783-92-2$ & 0.0012 & 0.0028 \\
\hline 108 & $\begin{array}{l}1 \mathrm{R}, 2 \mathrm{~T}, 4 \mathrm{C}, 5 \mathrm{~T}-1,2,4,5-\mathrm{Tetramethylcyclo-} \\
\text { hexane }\end{array}$ & & 0.0013 & 0.0030 \\
\hline 110 & 2-Heptanone, 3-methyl- & $2371-19-9$ & 0.0073 & 0.0047 \\
\hline 112 & 2-Heptanol, 2-methyl- and others & & 0.0019 & 0.0102 \\
\hline 14 & 2-Pentene, (Z) & $627-20-3$ & 0.044 & 0.008 \\
\hline 39 & 2-Propanol & $67-63-0$ & 0.30 & 0.05 \\
\hline 33 & 2-Hexene, (Z) & $7688-21-3$ & 0.038 & 0.006 \\
\hline 263 & 2-Pentadecanone, 6,10,14-trimethyl- & $502-69-2$ & 0.0029 & 0.0022 \\
\hline 31 & 2-Butanone & $78-93-3$ & 0.17 & 0.03 \\
\hline 10 & 2-Pentene, ( $\mathrm{C})$ & $627-20-3$ & 0.0053 & 0.0106 \\
\hline 118 & 2-Heptanone, 6-methyl- & $928-68-7$ & 0.049 & 0.026 \\
\hline 45 & 2-Butenal & $4170-30-3$ & 0.040 & 0.008 \\
\hline 46 & 2-Butanone, 3-methyl- & $563-80-4$ & 0.0031 & 0.0063 \\
\hline 268 & 2-Heptadecanone & $2922-51-2$ & 0.00042 & 0.00085 \\
\hline 269 & 2-Pentadecanone, 6,10,14-trimethyl- & $502-69-2$ & 0.00098 & 0.00113 \\
\hline 66 & 2-Pentanone, 4-methyl- & $108-10-1$ & 0.010 & 0.004 \\
\hline 56 & 2-Butanol & $78-92-2$ & 0.0015 & 0.0030 \\
\hline 64 & 2-Pentanol, 2-methyl- & $590-36-3$ & 0.010 & 0.002 \\
\hline 157 & 2-Nonanone & $821-55-6$ & 0.0047 & 0.0037 \\
\hline 59 & 2-Heptene & $592-77-8$ & 0.0080 & 0.0007 \\
\hline 57 & 2-Heptene & $592-77-8$ & 0.015 & 0.004 \\
\hline 75 & $\begin{array}{l}\text { 2,4-Hexadiene, 3-methyl- and } \\
\text { C2-Cyclohexane }\end{array}$ & & 0.0035 & 0.0041 \\
\hline
\end{tabular}


WHC-SD-WM-ER-419 REV. 2

\begin{tabular}{|c|c|c|c|c|}
\hline$\underset{\#}{\text { Cmpd }}$ & Compound & $\begin{array}{c}\mathrm{CAS}^{1} \\
\text { Number }\end{array}$ & $\begin{array}{c}\text { Average }^{2} \\
\left(\mathrm{mg} / \mathrm{m}^{3}\right)\end{array}$ & $\begin{array}{c}\text { Standard } \\
\text { Deviation } \\
\left(\mathrm{mg} / \mathrm{m}^{3}\right)\end{array}$ \\
\hline 202 & $\begin{array}{l}\text { 2(3H)-Benzofuranone, } \\
3 a, 4,5,6 \text {-tetrahydro-3a,6,6-trimethyl- }\end{array}$ & $16778-26-0$ & 0.014 & 0.001 \\
\hline 32 & 3-Hexene, (Z) & $7642-09-3$ & 0.019 & 0.004 \\
\hline 136 & 3-Hexene, 3-ethyl-2,5-dimethyl- & $62338-08-3$ & 0.0039 & 0.0006 \\
\hline 166 & 3-Decyne & 2384-85-2 & 0.0032 & 0.0025 \\
\hline 30 & 3-Buten-2-one & $78-94-4$ & 0.021 & 0.001 \\
\hline 55 & 3-Heptene, (E) & $14686-14-7$ & 0.0043 & 0.0029 \\
\hline 250 & 3-Hexadecene, (Z)- & $34303-81-6$ & 0.0012 & 0.0014 \\
\hline 104 & 3-Heptanol & $589-82-2$ & 0.011 & 0.003 \\
\hline 77 & 3-Hexanone & $589-38-8$ & 0.021 & 0.002 \\
\hline 102 & 3-Heptanone & $106-35-4$ & 0.047 & 0.021 \\
\hline 177 & 3-Undecene, 8-methyl- & & 0.0060 & 0.0031 \\
\hline 139 & 3-Hexene, 2,2,5,5-tetramethyl-and others & & 0.0061 & 0.0160 \\
\hline 98 & 4-Heptanone & $123-19-3$ & 0.016 & 0.006 \\
\hline 81 & 4-Octene, $(E)$ & $14850-23-8$ & 0.0100 & 0.0025 \\
\hline 88 & 4-Heptenal, (Z) & $6728-31-0$ & 0.0078 & 0.0008 \\
\hline 160 & 5-Undecene & $4941-53-1$ & 0.0034 & 0.0021 \\
\hline 156 & 5-Undecene & $4941-53-1$ & 0.016 & 0.005 \\
\hline 247 & 5-Undecanone, 2-methyl- & $50639-02-6$ & 0.0048 & 0.0034 \\
\hline 255 & 5-Undecanone, 2-methyl- & $50639-02-6$ & 0.0021 & 0.0015 \\
\hline 171 & 6-Methylundecane & $17302-33-9$ & 0.036 & 0.010 \\
\hline 167 & 6-Dodecene, $(E)$ & $7206-17-9$ & 0.0091 & 0.0032 \\
\hline 204 & 6-Tetradecene, cis & & 0.038 & 0.001 \\
\hline 83 & Acetic acid, butyl ester & $123-86-4$ & 0.0067 & 0.0016 \\
\hline 219 & Alkane & & 0.0044 & 0.0050 \\
\hline 233 & Alkane & & 0.0087 & 0.0100 \\
\hline 91 & Alkanol and alkene & & 0.0091 & 0.0005 \\
\hline 227 & Alkanol & & 0.0061 & 0.0041 \\
\hline 78 & Alkene & & 0.0045 & 0.0053 \\
\hline 85 & Alkene & & 0.0011 & 0.0021 \\
\hline
\end{tabular}


WHC-SD-WM-ER-419 REV. 2

\begin{tabular}{|c|c|c|c|c|}
\hline$\underset{\#}{\text { Cmpd }}$ & Compound & $\begin{array}{c}\mathrm{CAS}^{1} \\
\text { Number }\end{array}$ & $\begin{array}{c}\text { Average } \\
\left(\mathrm{mg} / \mathrm{m}^{3}\right)\end{array}$ & $\begin{array}{c}\text { Standard } \\
\text { Deviation } \\
\left(\mathrm{mg} / \mathrm{m}^{3}\right) \\
\end{array}$ \\
\hline 190 & Alkene & & 0.00098 & 0.00196 \\
\hline 185 & Alkenyl-cyclopentane & & 0.0041 & 0.0003 \\
\hline 126 & Alkyl-cyclohexene & & 0.0017 & 0.0037 \\
\hline 99 & Benzene, 1,2-dimethyl- & $95-47-6$ & 0.0079 & 0.0072 \\
\hline 120 & Benzene, propyl- & $103-65-1$ & 0.0010 & 0.0065 \\
\hline 158 & Benzenemethanol, a,a-dimethyl- & $617-94-7$ & 0.0090 & 0.0358 \\
\hline 262 & Benzenesulfonamide, N-butyl- & $3622-84-2$ & 0.029 & 0.007 \\
\hline 2 & Butane & $106-97-8$ & 0.47 & 0.05 \\
\hline 101 & Butane, $1,1^{\prime}$-oxybis- & $142-96-1$ & 0.0083 & 0.0158 \\
\hline 132 & Butanoic acid butyl ester & $109-21-7$ & 0.0066 & 0.0224 \\
\hline 165 & Butanoic acid, 2-hexenyl ester, (E) & $53398-83-7$ & 0.039 & 0.020 \\
\hline 174 & c11-alkene & & 0.010 & 0.002 \\
\hline 180 & C13-alkene & & 0.0019 & 0.0013 \\
\hline 207 & C14-alkane & & 0.011 & 0.001 \\
\hline 229 & C15-Alkane & & 0.013 & 0.002 \\
\hline 234 & C16-alkane & & 0.016 & 0.001 \\
\hline 176 & C2-decahydronaphthalene & & 0.0026 & 0.0025 \\
\hline 192 & C3-decahydronaphthalene & & 0.0020 & 0.0041 \\
\hline 193 & C3-decahydronaphthalene & & 0.013 & 0.008 \\
\hline 123 & C3-benzene and alkane & & 0.024 & 0.009 \\
\hline 194 & C3-decahydro-naphthalene & & 0.0068 & 0.0079 \\
\hline 44 & C4-Cyclopropane & & 0.0095 & 0.0189 \\
\hline 128 & C4-Cyclohexane & & 0.0014 & 0.0033 \\
\hline 145 & C5-Cyclohexane & & 0.0034 & 0.0037 \\
\hline 144 & C5-Cyclohexane & & 0.016 & 0.003 \\
\hline 13 & C5-alkene and C5-alkyne & & 0.20 & 0.03 \\
\hline 8 & C5-alkane & & 0.21 & 0.14 \\
\hline 26 & C6-alkene & & 0.0032 & 0.0064 \\
\hline 37 & C6-alkene and others & & 0.025 & 0.003 \\
\hline 29 & C6-aikene & & 0.21 & 0.03 \\
\hline
\end{tabular}


WHC-SD-WM-ER-419 REV. 2

\begin{tabular}{|c|c|c|c|c|}
\hline Cmpd & Compound & $\begin{array}{l}\mathrm{CAS}^{1} \\
\text { Number }\end{array}$ & $\begin{array}{l}\text { Average } \\
\left(\mathrm{mg} / \mathrm{m}^{3}\right)\end{array}$ & $\begin{array}{c}\text { Standard } \\
\text { Deviation } \\
\left(\mathrm{mg} / \mathrm{m}^{3}\right)\end{array}$ \\
\hline 23 & C6-alkene & & 0.030 & 0.008 \\
\hline 61 & C7-alkene & & 0.0011 & 0.0022 \\
\hline 201 & C7-cyclohexane & & 0.026 & 0.003 \\
\hline 240 & C7-Cyclohexane & & 0.0056 & 0.0008 \\
\hline 79 & C7-Alkene & & 0.0100 & 0.0054 \\
\hline 211 & C8-Cyclohexane & & 0.0012 & 0.0023 \\
\hline 69 & c8-alkene & & 0.027 & 0.004 \\
\hline 210 & C8-Cyclohexane & & 0.0067 & 0.0002 \\
\hline 117 & c9-alkene & & 0.0099 & 0.0136 \\
\hline 214 & C9-cyclopentane & & 0.0081 & 0.0004 \\
\hline 239 & C9-Cyclohexane & & 0.012 & 0.001 \\
\hline 238 & C9-Cyclopentane & $=$ & 0.0016 & 0.0032 \\
\hline 53 & Cyclobutane, isopropyl- & $872-56-0$ & 0.014 & 0.001 \\
\hline 125 & Cycloheptane, methoxy and others & & 0.0047 & 0.0037 \\
\hline 60 & Cyclohexane, methyl- & $108-87-2$ & 0.050 & 0.003 \\
\hline 74 & Cyclohexane, 1,3-dimethyl- & $638-04-0$ & 0.013 & 0.003 \\
\hline 89 & Cyclohexane, ethyl- & $1678-91-7$ & 0.016 & 0.002 \\
\hline 90 & Cyclohexane, 1,1,3-trimethyl- & $3073-66-3$ & 0.022 & 0.002 \\
\hline 94 & Cyclohexane, 1,3,5-trimethyl- & $1839-63-0$ & 0.0073 & 0.0019 \\
\hline 109 & Cyclohexane, 1-ethyl-4-methyl, trans- & $6236-88-0$ & 0.0068 & 0.0008 \\
\hline 114 & Cyclohexane, 1-propenyl- & $5364-83-0$ & 0.0030 & 0.0063 \\
\hline 127 & Cyclohexane, 1-methyl-4-(1-methylethyl) & $6069-98-3$ & 0.0072 & 0.0017 \\
\hline 129 & Cyclohexane, 1-methyl-4-(1-methylethyl) & $6069-98-3$ & 0.0049 & 0.0022 \\
\hline 135 & Cyclohexane, 1-methyl-3-propyi- & $4291-80-9$ & 0.0062 & 0.0015 \\
\hline 154 & $\begin{array}{l}\text { Cyclohexane, } \\
\text { 1-(cyclohexylmethyl)-4-methyl-, trans- }\end{array}$ & $54823-98-2$ & 0.0080 & 0.0020 \\
\hline 155 & Cyclohexane, 2,4-diethyl-1-methyl- & $61142-70-9$ & 0.0042 & 0.0062 \\
\hline 168 & Cyclohexane, pentyl- & $4292-92-6$ & 0.017 & 0.007 \\
\hline 181 & Cyclohexane, 1-methyl-3-pentyl- & $54411-02-8$ & 0.012 & 0.007 \\
\hline 182 & Cyclohexane, 1-methyl-4-(1-methylbutyl)- & $54411-00-6$ & 0.011 & 0.001 \\
\hline
\end{tabular}




\begin{tabular}{|c|c|c|c|c|}
\hline$\underset{\#}{\text { Cmpd }}$ & Compound & $\begin{array}{l}\text { CAS }^{1} \\
\text { Number }\end{array}$ & $\begin{array}{l}\text { Average }^{2} \\
\left(\mathrm{mg} / \mathrm{m}^{3}\right)\end{array}$ & $\begin{array}{c}\text { Standard } \\
\text { Deviation } \\
\left(\mathrm{mg} / \mathrm{m}^{3}\right) \\
\end{array}$ \\
\hline 191 & Cyclohexane, 2-butyl-1,1,3-trimethyl- & $54676-39-0$ & 0.023 & 0.001 \\
\hline 195 & Cyclohexane, hexyl- & $4292-75-5$ & 0.016 & 0.006 \\
\hline 216 & Cyclohexane, octyl- & $1795-15-9$ & 0.035 & 0.002 \\
\hline 225 & $\begin{array}{l}\text { Cyclohexane, } \\
\text { 1,1,3-trimethyl-2-(3-methylpentyl)- }\end{array}$ & $54965-05-8$ & 0.0085 & 0.0024 \\
\hline 254 & Cyclohexane, decyl & $1795-16-0$ & 0.0017 & 0.0011 \\
\hline 50 & Cyclohexene & $110-83-8$ & 0.0043 & 0.0051 \\
\hline 137 & Cyclooctane, 1,5-dimethyi- & $21328-57-4$ & 0.0063 & 0.0012 \\
\hline 21 & Cyclopentane & $287-92-3$ & 0.052 & 0.013 \\
\hline 63 & Cyclopentane, ethyl- & $1640-89-7$ & 0.010 & 0.001 \\
\hline 65 & Cyclopentane, 1,2,4-trimethyl- & $4850-28-6$ & 0.0066 & 0.0012 \\
\hline 134 & Cyciopentane, (2-methylbutyl)- & $53366-38-4$ & 0.00094 & 0.00266 \\
\hline 188 & $\begin{array}{l}\text { Cyclopentane, } \\
\text { 1,1,3-trimethyl-3-(2-methyl-2-propenyl)- }\end{array}$ & $74421-09-3$ & 0.0091 & 0.0004 \\
\hline 189 & Cyclopentane, 1-pentyl-2-propyl- & $62199-51-3$ & 0.0030 & 0.0004 \\
\hline 15 & Cyclopropane, ethyl- & $1191-96-4$ & 0.055 & 0.010 \\
\hline 16 & Cyclopropane, 1,1-dimethyl- & $1630-94-0$ & 0.029 & 0.006 \\
\hline 35 & Cyclopropane, 1,2-dimethyl-3-methylene & $4866-55-1$ & 0.020 & 0.004 \\
\hline 36 & Cyclopropane, propyl- & $2415-72-7$ & 0.035 & 0.004 \\
\hline 38 & Cyclopropane, (1-methylethyl)- & $3638-35-5$ & 0.081 & 0.013 \\
\hline 43 & Cyclopropane, butyl- & $930-57-4$ & 0.021 & 0.016 \\
\hline 51 & Cyclopropane, butyl- & $930-57-4$ & 0.0086 & 0.0016 \\
\hline 52 & Cyclopropane, butyl- & $930-57-4$ & 0.0086 & 0.0005 \\
\hline 54 & Cyclopropane, butyl- & $930-57-4$ & 0.091 & 0.007 \\
\hline 146 & $\begin{array}{l}\text { Cyclopropane, } \\
\text { 1,1,2-trimethyl-3-(2-methyipropyl)- }\end{array}$ & $41977-43-9$ & 0.0081 & 0.0001 \\
\hline 162 & Cyclopropane, 1-butyl-1-methyl-2-propyl- & $41977-34-8$ & 0.0049 & 0.0047 \\
\hline 131 & Cyclotetrasiloxane and C4-cyclohexane & & 0.023 & $\overline{0.009}$ \\
\hline 133 & Decane & $124-18-5$ & 0.058 & 0.029 \\
\hline 149 & Decane, 4-methyl- & $2847-72-5$ & 0.0073 & 0.0049 \\
\hline 150 & Decane, 2-methyl- & $6975-98-0$ & 0.021 & 0.003 \\
\hline
\end{tabular}




\begin{tabular}{|c|c|c|c|c|}
\hline$\underset{\#}{\text { Cmpd }}$ & Compound & $\begin{array}{l}\text { CAS }^{1} \\
\text { Number }\end{array}$ & $\begin{array}{l}\text { Average }^{2} \\
\left(\mathrm{mg} / \mathrm{m}^{3}\right)\end{array}$ & $\begin{array}{c}\text { Standard } \\
\text { Deviation } \\
\left(\mathrm{mg} / \mathrm{m}^{3}\right)\end{array}$ \\
\hline 179 & Decane, 2,3,6-trimethyl- & $62238-12-4$ & 0.010 & 0.005 \\
\hline 200 & Decane, 2,6,7-trimethyl- & $62108-25-2$ & 0.12 & 0.01 \\
\hline 220 & Decane, 2,3,8-trimethyl- & $62238-14-6$ & 0.0024 & 0.0047 \\
\hline 245 & Decane, 3-cyclohexyl, 3-cyclohexyl- & $13151-74-1$ & 0.016 & 0.002 \\
\hline 196 & Dodecane, 6-methyl- & $6044-71-9$ & 0.0082 & 0.0056 \\
\hline 198 & Dodecane, 4-methyl- & $6117-97-1$ & 0.017 & 0.001 \\
\hline 222 & Dodecane, 2,6,10-trimethyl- & $3891-98-3$ & 0.15 & 0.01 \\
\hline 226 & Dodecane, 2,6,11-trimethyl- & $31295-56-4$ & 0.019 & 0.0005 \\
\hline 228 & Dodecane, 2,6,11-trimethyl- & $31295-56-4$ & 0.024 & 0.002 \\
\hline 230 & $\begin{array}{l}\text { Dodecane, 2,6,11-trimethyl- or } \\
\text { C15-alkane }\end{array}$ & & 0.028 & 0.004 \\
\hline 244 & Dodecane, 2-methyl-8-propyi- & $55045-07-3$ & 0.014 & 0.004 \\
\hline 80 & Ethane, 1,2-dimethoxy- & $110-71-4$ & 0.0030 & 0.0060 \\
\hline 152 & Ethanone, 1-phenyl- & $98-86-2$ & 0.0084 & 0.0021 \\
\hline 82 & Ethene, tetrachloro- & $127-18-4$ & 0.0011 & 0.0021 \\
\hline 12 & Furan & $110-00-9$ & 0.039 & 0.028 \\
\hline 24 & Furan, 2,5-dihydro- & $1708-29-8$ & 0.022 & 0.004 \\
\hline 40 & Furan, tetrahydro- & $109-99-9$ & 0.25 & 0.03 \\
\hline 161 & Furan, 3-(1,1-dimethylethyl)2,3-dihydro- & $34314-82-4$ & 0.0038 & 0.0008 \\
\hline 257 & Heptadecane & $629-78-7$ & 0.0073 & 0.0049 \\
\hline 105 & Heptanal and others & & 0.0092 & 0.0050 \\
\hline 73 & Heptane, 3-methyl- & $589-81-1$ & 0.041 & 0.029 \\
\hline 87 & Heptane, 2,6-dimethyl- & $1072-05-5$ & 0.034 & 0.003 \\
\hline 95 & Heptane, 2,3-dimethyl- & $3074-71-3$ & 0.0088 & 0.0077 \\
\hline 100 & Heptane, 2,5-dimethyl- & $2216-30-0$ & 0.018 & 0.007 \\
\hline 116 & Heptane, 3-ethyl-2-methyl- & $14676-29-0$ & 0.0071 & 0.0003 \\
\hline 231 & Hexadecane & $544-76-3$ & 0.16 & 0.01 \\
\hline 246 & Hexadecane, 2-methyl- & $1560-92-5$ & 0.0066 & 0.0044 \\
\hline 249 & Hexadecane & $544-76-3$ & 0.051 & 0.017 \\
\hline 271 & Hexadecane, 2,6,10,14-tetramethyl- & $638-36-8$ & 0.00055 & 0.00109 \\
\hline
\end{tabular}


WHC-SD-WM-ER-419 REV. 2

\begin{tabular}{|c|c|c|c|c|}
\hline $\begin{array}{c}\text { Cmpd } \\
\#\end{array}$ & Compound & $\begin{array}{c}\text { CAS }^{1} \\
\text { Number }\end{array}$ & $\begin{array}{c}\text { Average }{ }^{2} \\
\left(\mathrm{mg} / \mathrm{m}^{3}\right)\end{array}$ & $\begin{array}{l}\text { Standard } \\
\text { Deviation } \\
\left(\mathrm{mg} / \mathrm{m}^{3}\right) \\
\end{array}$ \\
\hline 270 & Hexadecanoic acid & $57-10-3$ & 0.0085 & 0.0058 \\
\hline 272 & Hexadecanoic acid, 1-methylethyl ester & $142-91-6$ & 0.0041 & 0.0029 \\
\hline 84 & Hexamethylcyclotrisiloxane & $541-05-9$ & 0.0078 & 0.0011 \\
\hline 47 & Hexane, 2-methyl- & $591-76-4$ & 0.058 & 0.002 \\
\hline 62 & Hexane, 2,4-dimethyl- & $589-43-5$ & 0.0021 & 0.0024 \\
\hline 71 & Hexane, 2,3-dimethyl- & $584-94-1$ & 0.034 & 0.002 \\
\hline 266 & Hexanedioic acid, dioctyl ester & $123-79-5$ & 0.0016 & 0.0031 \\
\hline 7 & Methane, oxybis (methyl ether) & $115-10-6$ & 0.027 & 0.008 \\
\hline 9 & Methane, trichlorofluoro- & $75-69-4$ & 0.14 & 0.03 \\
\hline 68 & Mixture & & 0.0057 & 0.0005 \\
\hline 72 & Mixture & & 0.016 & 0.026 \\
\hline 92 & Mixture & & 0.013 & 0.006 \\
\hline 93 & Mixture & & 0.0093 & 0.0045 \\
\hline 111 & Mixture & & 0.020 & 0.011 \\
\hline 141 & Mixture & & 0.0046 & 0.0009 \\
\hline 143 & Mixture & & 0.0058 & 0.0045 \\
\hline 212 & Mixture & & 0.0012 & 0.0025 \\
\hline 213 & Mixture & $\cdot$ & 0.0084 & 0.0005 \\
\hline 267 & Mixture & & 0.0012 & 0.0025 \\
\hline 151 & Naphthalene, decahydro, trans- & $493-02-7$ & 0.029 & 0.008 \\
\hline 169 & Naphthalene, decahydro-2-methyl- & $2958-76-1$ & 0.032 & 0.014 \\
\hline 178 & Naphthalene, decahydro, 1,5-dimethyl- & $66552-62-3$ & 0.0036 & 0.0045 \\
\hline 121 & Nonane, 4-methyl- & $17301-94-9$ & 0.013 & 0.010 \\
\hline 140 & Nonane, 2,6-dimethyi- & $17302-28-2$ & 0.042 & 0.022 \\
\hline 147 & Nonane, 4,5-dimethyl- & $17302-23-7$ & 0.0061 & 0.0054 \\
\hline 186 & Nonane, 5-butyl- & $17312-63-9$ & 0.012 & 0.0002 \\
\hline 260 & Octadecane & $593-45-3$ & 0.0011 & 0.0013 \\
\hline 96 & Octane, 4-methyl- & $2216-34-4$ & 0.028 & 0.003 \\
\hline 97 & Octane, 3-methyl- & $2216-33-3$ & 0.036 & 0.019 \\
\hline 113 & Octane, 2,6-dimethyl- & $2051-30-1$ & 0.027 & 0.014 \\
\hline \multicolumn{5}{|c|}{42} \\
\hline
\end{tabular}




\begin{tabular}{|c|c|c|c|c|}
\hline$\underset{\#}{\text { Cmpd }}$ & Compound & $\begin{array}{l}\mathrm{CAS}^{1} \\
\text { Number }\end{array}$ & $\begin{array}{l}\text { Average }^{2} \\
\left(\mathrm{mg} / \mathrm{m}^{3}\right)\end{array}$ & $\begin{array}{l}\text { Standard } \\
\text { Deviation } \\
\left(\mathrm{mg} / \mathrm{m}^{3}\right) \\
\end{array}$ \\
\hline 119 & Octane, 3,4-dimethyl- & $15869-92-8$ & 0.0062 & 0.0067 \\
\hline 124 & Octane, 2,3,7-trimethyl- & $62016-34-6$ & 0.016 & 0.006 \\
\hline 236 & Pentadecane & $629-62-9$ & 0.14 & 0.03 \\
\hline 248 & Pentadecane & $629-62-9$ & 0.0043 & 0.0028 \\
\hline 253 & Pentadecane, 2,6,10-trimethyl- & $3892-00-0$ & 0.015 & 0.004 \\
\hline 258 & Pentadecane, 2,6,10,14-tetramethyl- & $1921-70-6$ & 0.0076 & 0.0027 \\
\hline 264 & Pentadecanoic acid & $1002-84-2$ & 0.00097 & 0.00193 \\
\hline 22 & Pentane, 2-methyl- & $107-83-5$ & 0.69 & 0.07 \\
\hline 27 & Pentane, 3-methyl- & $96-14-0$ & 0.14 & 0.02 \\
\hline 58 & Pentane, 2,4-dimethyl- & $108-08-7$ & 0.011 & 0.001 \\
\hline 130 & Phenol & $108-95-2$ & 0.014 & 0.005 \\
\hline 153 & Phenol, 3-methyl- & $108-39-4$ & 0.012 & 0.002 \\
\hline 205 & Phenol, 4-(1,1-dimethylethyl)- and others & & 0.0055 & 0.0005 \\
\hline 251 & $\begin{array}{l}\text { Propanoic acid, 2-methyl-,1-(1,1-dimethyl- } \\
\text { ethyl)-2-methyl-1,3- propanediyl ester }\end{array}$ & $74381-40-1$ & 0.026 & 0.017 \\
\hline 86 & Pyridine, 3-methyl- & $108-99-6$ & 0.0039 & 0.0044 \\
\hline 115 & Pyridine, 3,5-dimethyl- and others & & 0.012 & 0.004 \\
\hline 261 & Siloxane & & 0.0011 & 0.0012 \\
\hline 103 & Styrene & $100-42-5$ & 0.0059 & 0.0008 \\
\hline 215 & Tetradecane & $629-59-4$ & 0.017 & 0.001 \\
\hline 223 & Tetradecane & $629-59-4$ & 0.15 & 0.03 \\
\hline 232 & Tetradecane, 3-methyl- & $18435-22-8$ & 0.024 & 0.005 \\
\hline 242 & Tetradecane, 2,6,10-trimethyl- & $14905-56-7$ & 0.017 & 0.003 \\
\hline 243 & Tetradecane, 4,11-dimethyl- & $55045-12-0$ & 0.0047 & 0.0055 \\
\hline 259 & Tetradecanoic acid & $544-63-8$ & 0.0080 & 0.0040 \\
\hline 208 & Tridecane, 6-methyl- & $13287-21-3$ & 0.033 & 0.003 \\
\hline 217 & Tridecane, 4-methyl- & $26730-12-1$ & 0.023 & 0.003 \\
\hline 218 & Tridecane, 2-methyl- & $1560-96-9$ & 0.029 & 0.005 \\
\hline 221 & Tridecane, 3-methyl- & $6418-41-3$ & 0.046 & 0.003 \\
\hline 224 & Tridecane, 4,8-dimethyl- & $55030-62-1$ & 0.029 & 0.001 \\
\hline
\end{tabular}


WHC-SD-WM-ER-419 REV. 2

\begin{tabular}{clccc}
\hline \hline $\begin{array}{c}\text { Cmpd } \\
\#\end{array}$ & Compound & $\begin{array}{c}\text { CAS' } \\
\text { Number }\end{array}$ & $\begin{array}{c}\text { Average } \\
\left(\mathrm{mg} / \mathrm{m}^{3}\right)\end{array}$ & $\begin{array}{c}\text { Standard } \\
\text { Deviation } \\
\left(\mathrm{mg}^{3} / \mathrm{m}^{3}\right)\end{array}$ \\
\hline \hline 241 & Tridecane, 5-propyl- & $55045-11-9$ & 0.0023 & 0.0016 \\
159 & Undecane & $1120-21-4$ & 0.088 & 0.043 \\
163 & Undecane, 5-methyl- & $1632-70-8$ & 0.015 & 0.003 \\
172 & Undecane, 4-methyl- & $2980-69-0$ & 0.019 & 0.004 \\
173 & Undecane, 2-methyl- & $7045-71-8$ & 0.032 & 0.012 \\
175 & Undecane, 3-methyl- & $1002-43-3$ & 0.014 & 0.005 \\
183 & Undecane, 2,4-dimethyl- and others & & 0.0019 & 0.0022 \\
184 & Undecane, 2,6-dimethyl- & $17301-23-4$ & 0.066 & 0.003 \\
187 & Undecane, 3-methyl- & $1002-43-3$ & 0.0034 & 0.0004 \\
197 & Undecane, 2,4-dimethyl- & $17312-80-0$ & 0.0064 & 0.0004 \\
199 & Undecane, 2,10-dimethyl- & $17301-27-8$ & 0.039 & 0.003 \\
206 & Undecane, 2,4-dimethyl- & $17312-80-0$ & 0.0048 & 0.0005 \\
76 & Unknown & & 0.0012 & 0.0025 \\
Sum of tentatively identified compounds: & & 8.60 & \\
\hline \hline
\end{tabular}

1 CAS $=$ Chemical Abstract Service.

2 Average of 4, 4-L TST samples analyses, values listed are estimates. 
Table 4-9

Tank BY-105 Tentatively Identified Organic Compounds in TST Samples Sorted by Estimated Concentration -Analyses Conducted by Oak Ridge National Laboratory

\begin{tabular}{|c|c|c|c|c|}
\hline$\underset{\#}{C \text { Cmpd }}$ & Compound & $\begin{array}{c}\mathrm{CAS}^{1} \\
\text { Number }\end{array}$ & $\begin{array}{l}\text { Average } \\
\left(\mathrm{mg} / \mathrm{m}^{3}\right)\end{array}$ & $\begin{array}{c}\text { Standard } \\
\text { Deviation } \\
\left(\mathrm{mg} / \mathrm{m}^{3}\right)\end{array}$ \\
\hline 22 & Pentane, 2-methyl- & $107-83-5$ & 0.69 & 0.07 \\
\hline 1 & 1-Butene or C4-alkene & $106-98-9$ & 0.57 & 0.05 \\
\hline 2 & Butane & $106-97-8$ & 0.47 & 0.05 \\
\hline 11 & 1-Pentene & $109-67-1$ & 0.38 & 0.05 \\
\hline 39 & 2-Propanol & $67-63-0$ & 0.30 & 0.05 \\
\hline 40 & Furan, tetrahydro- & $109-99-9$ & 0.25 & 0.03 \\
\hline 29 & C6-alkene & & 0.21 & 0.03 \\
\hline 8 & C5-alkane & & 0.21 & 0.14 \\
\hline 13 & C5-alkene and C5-alkyne & & 0.20 & 0.03 \\
\hline 31 & 2-Butanone & $78-93-3$ & 0.17 & 0.03 \\
\hline 231 & Hexadecane & $544-76-3$ & 0.16 & 0.01 \\
\hline 20 & 1-Pentene, 4-methyl- & $691-37-2$ & 0.15 & 0.01 \\
\hline 222 & Dodecane, 2,6,t0-trimethyl- & $3891-98-3$ & 0.15 & 0.01 \\
\hline 223 & Tetradecane & $629-59-4$ & 0.15 & 0.03 \\
\hline 9 & Methane, trichlorofluoro- & $75-69-4$ & 0.14 & 0.03 \\
\hline 236 & Pentadecane & $629-62-9$ & 0.14 & 0.03 \\
\hline 27 & Pentane, 3-methyl- & $96-14-0$ & 0.14 & 0.02 \\
\hline 200 & Decane, 2,6,7-trimethyl- & $62108-25-2$ & 0.12 & 0.01 \\
\hline 54 & Cyclopropane, butyl- & $930-57-4$ & 0.091 & 0.007 \\
\hline 159 & Undecane & $1120-21-4$ & 0.088 & 0.043 \\
\hline 38 & Cyclopropane, (1-methylethyl)- & $3638-35-5$ & 0.081 & 0.013 \\
\hline 3 & 1-Propene,2-methyl or C4-alkene & $115-11-7$ & 0.079 & 0.006 \\
\hline 5 & 1-Propene,2-methyl or C4-alkene & $115-11-7$ & 0.073 & 0.005 \\
\hline 4 & 1-Propene,2-methyl- or C4 alkene & $115-11-7$ & 0.073 & 0.050 \\
\hline 6 & 1-Butene,3-methyl- & $563-45-1$ & 0.068 & 0.008 \\
\hline 184 & Undecane, 2,6-dimethyl- & $17301-23-4$ & 0.066 & 0.003 \\
\hline 47 & Hexane, 2-methyl- & $591-76-4$ & 0.058 & 0.002 \\
\hline
\end{tabular}




\begin{tabular}{|c|c|c|c|c|}
\hline$\underset{\#}{C \text { Cmpd }}$ & Compound & $\begin{array}{c}\text { CAS }^{1} \\
\text { Number }\end{array}$ & $\begin{array}{l}\text { Average }^{2} \\
\left(\mathrm{mg} / \mathrm{m}^{3}\right)\end{array}$ & $\begin{array}{c}\text { Standard } \\
\text { Deviation } \\
\left(\mathrm{mg} / \mathrm{m}^{3}\right)\end{array}$ \\
\hline 28 & 1.Pentene, 2-methyl- & $763-29-1$ & 0.058 & 0.039 \\
\hline 133 & Decane & $124-18-5$ & 0.058 & 0.029 \\
\hline 15 & Cyclopropane, ethyl- & $1191-96-4$ & 0.055 & 0.010 \\
\hline 21 & Cyclopentane & $287-92-3$ & 0.052 & 0.013 \\
\hline 249 & Hexadecane & $544-76-3$ & 0.051 & 0.017 \\
\hline 60 & Cyclohexane, methyl- & $108-87-2$ & 0.050 & 0.003 \\
\hline 118 & 2-Heptanone, 6-methyl- & $928-68-7$ & 0.049 & 0.026 \\
\hline 102 & 3-Heptanone & $106-35-4$ & 0.047 & 0.021 \\
\hline 41 & 1,3-Pentadiene, 2-methyl- & $1118-58-7$ & 0.047 & 0.012 \\
\hline 221 & Tridecane, 3-methyl- & $6418-41-3$ & 0.046 & 0.003 \\
\hline 14 & 2-Pentene, $(Z)$ & $627-20-3$ & 0.044 & 0.008 \\
\hline 140 & Nonane, 2,6-dimethyl- & $17302-28-2$ & 0.042 & 0.022 \\
\hline 73 & Heptane, 3-methyl- & $589-81-1$ & 0.041 & 0.029 \\
\hline 45 & 2-Butenal & $4170-30-3$ & 0.040 & 0.008 \\
\hline 199 & Undecane, 2,10-dimethyl- & $17301-27-8$ & 0.039 & 0.003 \\
\hline 12 & Furan & $110-00-9$ & 0.039 & 0.028 \\
\hline 165 & Butanoic acid, 2-hexenyl ester, $(E)$ & $53398-83-7$ & 0.039 & 0.020 \\
\hline 33 & 2-Hexene, (Z) & $7688-21-3$ & 0.038 & 0.006 \\
\hline 204 & 6-Tetradecene, cis & & 0.038 & 0.001 \\
\hline 97 & Octane, 3-methyl- & $2216-33-3$ & 0.036 & 0.019 \\
\hline 171 & 6-Methylundecane & $17302-33-9$ & 0.036 & 0.010 \\
\hline 36 & Cyclopropane, propyl- & $2415-72-7$ & 0.035 & 0.004 \\
\hline 216 & Cyclohexane, octyl- & $1795-15-9$ & 0.035 & 0.002 \\
\hline 87 & Heptane, 2,6-dimethyl- & $1072-05-5$ & 0.034 & 0.003 \\
\hline 71 & Hexane, 2,3-dimethyl- & $584-94-1$ & 0.034 & 0.002 \\
\hline 42 & 1,4-Hexadiene & $592-45-0$ & 0.033 & 0.007 \\
\hline 208 & Tridecane, 6-methyl- & $13287-21-3$ & 0.033 & 0.003 \\
\hline 18 & 1,2-Pentadiene & $591-95-7$ & 0.032 & 0.007 \\
\hline 169 & Naphthalene, decahydro-2-methyl- & $2958-76-1$ & 0.032 & 0.014 \\
\hline 173 & Undecane, 2-methyi- & $7045-71-8$ & 0.032 & 0.012 \\
\hline
\end{tabular}


WHC-SD-WM-ER-419 REV. 2

\begin{tabular}{|c|c|c|c|c|}
\hline$\underset{\#}{\text { Cmpd }}$ & Compound & $\begin{array}{l}\mathrm{CAS}^{1} \\
\text { Number }\end{array}$ & $\begin{array}{l}\text { Average }^{2} \\
\left(\mathrm{mg} / \mathrm{m}^{3}\right)\end{array}$ & $\begin{array}{c}\text { Standard } \\
\text { Deviation } \\
\left(\mathrm{mg} / \mathrm{m}^{3}\right) \\
\end{array}$ \\
\hline 23 & C6-alkene & & 0.030 & 0.008 \\
\hline 224 & Tridecane, 4,8-dimethyl- & $55030-62-1$ & 0.029 & 0.001 \\
\hline 16 & Cyclopropane, 1,1-dimethyl- & $1630-94-0$ & 0.029 & 0.006 \\
\hline 218 & Tridecane, 2-methyl- & $1560-96-9$ & 0.029 & 0.005 \\
\hline 262 & Benzenesulfonamide, N-butyl- & $3622-84-2$ & 0.029 & 0.007 \\
\hline 151 & Naphthalene, decahydro, trans- & $493-02-7$ & 0.029 & 0.008 \\
\hline 230 & $\begin{array}{l}\text { Dodecane, 2,6,11-trimethyl- or } \\
\text { C15-alkane }\end{array}$ & & 0.028 & 0.004 \\
\hline 96 & Octane, 4-methyl- & $2216-34-4$ & 0.028 & 0.003 \\
\hline 122 & 1,1,2,3-tetramethylcyclohexane & $6783-92-2$ & 0.027 & 0.005 \\
\hline 7 & Methane, oxybis (methyl ether) & $115-10-6$ & 0.027 & 0.008 \\
\hline 113 & Octane, 2,6-dimethyl- & $2051-30-1$ & 0.027 & 0.014 \\
\hline 69 & C8-alkene & & 0.027 & 0.004 \\
\hline 251 & $\begin{array}{l}\text { Propanoic acid, 2-methyl-,1-(1,1-dimethyl- } \\
\text { ethyl)-2-methyl-1,3- propanediyl ester }\end{array}$ & $74381-40-1$ & 0.026 & 0.017 \\
\hline 201 & C7-cyclohexane & & 0.026 & 0.003 \\
\hline 34 & 1-Butene, 2,3-dimethyl- & $563-78-0$ & 0.026 & 0.006 \\
\hline 235 & 1-Hexadecene & $629-73-2$ & 0.025 & 0.001 \\
\hline 37 & c6-alkene and others & & 0.025 & 0.003 \\
\hline 123 & C3-benzene and alkane & & 0.024 & 0.009 \\
\hline 228 & Dodecane, 2,6,11-trimethyl- & $31295-56-4$ & 0.024 & 0.002 \\
\hline 232 & Tetradecane, 3-methyl- & $18435-22-8$ & 0.024 & 0.005 \\
\hline 217 & Tridecane, 4-methyl- & $26730-12-1$ & 0.023 & 0.003 \\
\hline 191 & Cyclohexane, 2-butyl-1,1,3-trimethyl- & $54676-39-0$ & 0.023 & 0.001 \\
\hline 131 & Cyclotetrasiloxane and C4-cyclohexane. & & 0.023 & 0.009 \\
\hline 90 & Cyclohexane, 1,1,3-trimethyl- & $3073-66-3$ & 0.022 & 0.002 \\
\hline 24 & Furàn, 2,5-dihydro- & $1708-29-8$ & 0.022 & 0.004 \\
\hline 30 & 3-Buten-2-one & $78-94-4$ & 0.021 & 0.001 \\
\hline 77 & 3-Hexanone & $589-38-8$ & 0.021 & 0.002 \\
\hline 150 & Decane, 2-methyl- & $6975-98-0$ & 0.021 & 0.003 \\
\hline 43 & Cyclopropane, butyl- & $930-57-4$ & 0.021 & 0.016 \\
\hline
\end{tabular}


WHC-SD-WM-ER-419 REV. 2

\begin{tabular}{|c|c|c|c|c|}
\hline Cmpd & Compound & $\begin{array}{l}\text { CAS }^{1} \\
\text { Number }\end{array}$ & $\begin{array}{l}\text { Average }^{2} \\
\left(\mathrm{mg} / \mathrm{m}^{3}\right)\end{array}$ & $\begin{array}{c}\text { Standard } \\
\text { Deviation } \\
\left(\mathrm{mg} / \mathrm{m}^{3}\right)\end{array}$ \\
\hline 35 & Cyclopropane, 1,2-dimethyl-3-methylene & $4866-55-1$ & 0.020 & 0.004 \\
\hline 111 & Mixture & & 0.020 & 0.011 \\
\hline 226 & Dodecane, 2,6,11-trimethyl- & $31295-56-4$ & 0.019 & 0.0005 \\
\hline 148 & 1,1-Dimethyl-2-propylcyclohexane & & 0.019 & 0.007 \\
\hline 172 & Undecane, 4-methyl- & $2980-69-0$ & 0.019 & 0.004 \\
\hline 32 & 3-Hexene, (Z) & $7642-09-3$ & 0.019 & 0.004 \\
\hline 100 & Heptane, 2,5-dimethyl- & $2216-30-0$ & 0.018 & 0.007 \\
\hline 215 & Tetradecane & $629-59-4$ & 0.017 & 0.001 \\
\hline 198 & Dodecane, 4-methyl- & $6117-97-1$ & 0.017 & 0.001 \\
\hline 168 & Cyclohexane, pentyl- & $4292-92-6$ & 0.017 & 0.007 \\
\hline 242 & Tetradecane, 2,6,10-trimethyl- & $14905-56-7$ & 0.017 & 0.003 \\
\hline 98 & 4-Heptanone & $123-19-3$ & 0.016 & 0.006 \\
\hline 195 & Cyclohexane, hexyl- & $4292-75-5$ & 0.016 & 0.006 \\
\hline 89 & Cyciohexane, ethyl- & $1678-91-7$ & 0.016 & 0.002 \\
\hline 144 & C5-Cyclohexane & & 0.016 & 0.003 \\
\hline 245 & Decane, 3-cyclohexyl, 3-cyclohexyl- & $13+51-74-1$ & 0.016 & 0.002 \\
\hline 72 & Mixture & & 0.016 & 0.026 \\
\hline 234 & c16-alkane & & 0.016 & 0.001 \\
\hline 124 & Octane, 2,3,7-trimethyl- & $62016-34-6$ & 0.016 & 0.006 \\
\hline 156 & 5-Undecene & $4941-53-1$ & 0.016 & 0.005 \\
\hline 57 & 2-Heptene & $592-77-8$ & 0.015 & 0.004 \\
\hline 253 & Pentadecane, 2,6,10-trimethyl- & $3892-00-0$ & 0.015 & 0.004 \\
\hline 163 & Undecane, 5-methyl- & $1632-70-8$ & 0.015 & 0.003 \\
\hline 175 & Undecane, 3-methyl- & $1002-43-3$ & 0.014 & 0.005 \\
\hline 53 & Cyclobutane, isopropyl- & $872-56-0$ & 0.014 & 0.001 \\
\hline 202 & $\begin{array}{l}\text { 2(3H)-Benzofuranone, } \\
3 a, 4,5,6 \text {-tetrahydro-3a,6,6-trimethyl- }\end{array}$ & $16778-26-0$ & 0.014 & 0.001 \\
\hline 244 & Dodecane, 2-methyl-8-propyl- & $55045-07-3$ & 0.014 & 0.004 \\
\hline 130 & Phenol & $108-95-2$ & 0.014 & 0.005 \\
\hline 229 & C15-Alkane & & 0.013 & 0.002 \\
\hline
\end{tabular}


WHC-SD-WM-ER-419 REV. 2

\begin{tabular}{|c|c|c|c|c|}
\hline $\begin{array}{c}\text { Cmpd } \\
\#\end{array}$ & Compound & $\begin{array}{c}\text { CAS }^{1} \\
\text { Number }\end{array}$ & $\begin{array}{l}\text { Average }^{2} \\
\left(\mathrm{mg} / \mathrm{m}^{3}\right)\end{array}$ & $\begin{array}{l}\text { Standard } \\
\text { Deviation } \\
\left(\mathrm{mg} / \mathrm{m}^{3}\right)\end{array}$ \\
\hline 17 & 1-Pentyne and C5-alkene & & 0.013 & 0.009 \\
\hline 92 & Mixture & & 0.013 & 0.006 \\
\hline 193 & C3-decahydronaphthalene & & 0.013 & 0.008 \\
\hline 74 & Cyclohexane, 1,3-dimethyl- & $638-04-0$ & 0.013 & 0.003 \\
\hline 121 & Nonane, 4-methyl- & $17301-94-9$ & 0.013 & 0.010 \\
\hline 115 & Pyridine, 3,5-dimethyl- and others & & 0.012 & 0.004 \\
\hline 239 & C9-Cyclohexane & & 0.012 & 0.001 \\
\hline 181 & Cyclohexane, 1-methyl-3-pentyl- & $54411-02-8$ & 0.012 & 0.007 \\
\hline 153 & Phenol, 3-methyl- & $108-39-4$ & 0.012 & 0.002 \\
\hline 186 & Nonane, 5-butyl- & $17312-63-9$ & 0.012 & 0.0002 \\
\hline 58 & Pentane, 2,4-dimethyl- & $108-08-7$ & 0.011 & 0.001 \\
\hline 207 & c14-alkane & & 0.011 & 0.001 \\
\hline 104 & 3-Heptanol & $589-82-2$ & 0.011 & 0.003 \\
\hline 182 & Cyclohexane, 1-methyl-4-(1-methylbutyl)- & $54411-00-6$ & 0.011 & 0.001 \\
\hline 179 & Decane, 2,3,6-trimethyl- & $62238-12-4$ & 0.010 & 0.005 \\
\hline 66 & 2-Pentanone, 4-methyl- & $108-10-1$ & 0.010 & 0.004 \\
\hline 81 & 4-Octene, (E) & $14850-23-8$ & 0.0100 & 0.0025 \\
\hline 63 & Cyclopentane, ethyl- & $1640-89-7$ & 0.010 & 0.001 \\
\hline 79 & C7-Alkene & & 0.0100 & 0.0054 \\
\hline 174 & c11-alkene & & 0.010 & 0.002 \\
\hline 64 & 2-Pentanol, 2-methyl- & $590-36-3$ & 0.010 & 0.002 \\
\hline 117 & C9-alkene & & 0.0099 & 0.0136 \\
\hline 252 & 1,2-Benzenedicarboxylic acid, diethyl ester & $84-66-2$ & 0.0095 & 0.0190 \\
\hline 44 & C4-Cyclopropane & & 0.0095 & 0.0189 \\
\hline 93 & Mixture & & 0.0093 & 0.0045 \\
\hline 105 & Heptanal and others & & 0.0092 & 0.0050 \\
\hline 188 & $\begin{array}{l}\text { Cyclopentane, } \\
\text { 1,1,3-trimethyl-3-(2-methyl-2-propenyl)- }\end{array}$ & $74421-09-3$ & 0.0091 & 0.0004 \\
\hline 167 & 6-Dodecene, $(E)$ & $7206-17-9$ & 0.0091 & 0.0032 \\
\hline 164 & 1-Nonyne & $3452-09-3$ & 0.0091 & 0.0134 \\
\hline
\end{tabular}




\begin{tabular}{|c|c|c|c|c|}
\hline$\underset{\#}{\text { Cmpd }}$ & Compound & $\begin{array}{c}\text { CAS }^{1} \\
\text { Number }\end{array}$ & $\begin{array}{l}\text { Average }^{2} \\
\left(\mathrm{mg} / \mathrm{m}^{3}\right)\end{array}$ & $\begin{array}{c}\text { Standard } \\
\text { Deviation } \\
\left(\mathrm{mg} / \mathrm{m}^{3}\right)\end{array}$ \\
\hline 91 & Alkanol and alkene & & 0.0091 & 0.0005 \\
\hline 158 & Benzenemethanol, a,a-dimethyl- & $617-94-7$ & 0.0090 & 0.0358 \\
\hline 95 & Heptane, 2,3-dimethyl- & $3074-71-3$ & 0.0088 & 0.0077 \\
\hline 233 & Alkane & & 0.0087 & 0.0100 \\
\hline 51 & Cyclopropane, butyl- & $930-57-4$ & 0.0086 & 0.0016 \\
\hline 52 & Cyclopropane, butyl- & $930-57.4$ & 0.0086 & 0.0005 \\
\hline 270 & Hexadecanoic acid & $57-10-3$ & 0.0085 & 0.0058 \\
\hline 225 & $\begin{array}{l}\text { Cyclohexane, } \\
\text { 1,1,3-trimethyl-2-(3-methylpentyi)- }\end{array}$ & $54965-05-8$ & 0.0085 & 0.0024 \\
\hline 213 & Mixture & & 0.0084 & 0.0005 \\
\hline 152 & Ethanone, 1-phenyl- & $98-86-2$ & 0.0084 & 0.0021 \\
\hline 101 & Butane, $1,1^{\prime}$-oxybis- & $142-96-1$ & 0.0083 & 0.0158 \\
\hline 196 & Dodecane, 6-methyl- & $6044-71-9$ & 0.0082 & 0.0056 \\
\hline 214 & C9-cyclopentane & & 0.0081 & 0.0004 \\
\hline 146 & $\begin{array}{l}\text { Cyclopropane, } \\
\text { 1,1,2-trimethyi-3-(2-methylpropyi)- }\end{array}$ & $41977-43-9$ & 0.0081 & 0.0001 \\
\hline 154 & $\begin{array}{l}\text { Cyclohexane, } \\
\text { 1-(cyclohexyimethyl)-4-methyl-, trans- }\end{array}$ & $54823-98-2$ & 0.0080 & 0.0020 \\
\hline 59 & 2-Heptene & $592-77-8$ & 0.0080 & 0.0007 \\
\hline 259 & Tetradecanoic acid & $544-63-8$ & 0.0080 & 0.0040 \\
\hline 99 & Benzene, 1,2-dimethyl- & $95-47-6$ & 0.0079 & 0.0072 \\
\hline 84 & Hexamethylcyclotrisiloxane & $541-05-9$ & 0.0078 & 0.0011 \\
\hline 25 & 1-Hexene & $592-41-6$ & 0.0078 & 0.0090 \\
\hline 88 & 4-Heptenal, (Z) & $6728-31-0$ & 0.0078 & 0.0008 \\
\hline 258 & Pentadecane, 2,6,10,14-tetramethyl- & $1921-70-6$ & 0.0076 & 0.0027 \\
\hline 257 & Heptadecane & $629-78-7$ & 0.0073 & 0.0049 \\
\hline 110 & 2-Heptanone, 3-methyl- & $2371-19-9$ & 0.0073 & 0.0047 \\
\hline 149 & Decane, 4-methyl- & $2847-72-5$ & 0.0073 & 0.0049 \\
\hline 94 & Cyclohexane, 1,3,5-trimethyl- & $1839-63-0$ & 0.0073 & 0.0019 \\
\hline 127 & Cyclohexane, 1-methyl-4-(1-methylethyl) & $6069-98-3$ & 0.0072 & 0.0017 \\
\hline 142 & 1-Hexanol, 2-ethyl- & $104-76-7$ & 0.0071 & 0.0015 \\
\hline
\end{tabular}


WHC-SD-WM-ER-419 REV. 2

\begin{tabular}{|c|c|c|c|c|}
\hline$\underset{\#}{\text { Cmpd }}$ & Compound & $\begin{array}{c}\mathrm{CAS}^{1} \\
\text { Number }\end{array}$ & $\begin{array}{l}\text { Average }^{2} \\
\left(\mathrm{mg} / \mathrm{m}^{3}\right)\end{array}$ & $\begin{array}{c}\text { Standard } \\
\text { Deviation } \\
\left(\mathrm{mg} / \mathrm{m}^{3}\right)\end{array}$ \\
\hline 116 & Heptane, 3-ethyl-2-methyl- & $14676-29-0$ & 0.0071 & 0.0003 \\
\hline 109 & Cyclohexane, 1-ethyl-4-methyl, trans- & $6236-88-0$ & 0.0068 & 0.0008 \\
\hline 194 & C3-decahydro-naphthalene & & 0.0068 & 0.0079 \\
\hline 83 & Acetic acid, butyl ester & $123-86-4$ & 0.0067 & 0.0016 \\
\hline 210 & C8-Cyclohexane & & 0.0067 & 0.0002 \\
\hline 132 & Butanoic acid butyl ester & $109-21-7$ & 0.0066 & 0.0224 \\
\hline 65 & Cyclopentane, 1,2,4-trimethyl- & $4850-28-6$ & 0.0066 & 0.0012 \\
\hline 246 & Hexadecane, 2-methyl- & $1560-92-5$ & 0.0066 & 0.0044 \\
\hline 197 & Undecane, 2,4-dimethyl- & $17312-80-0$ & 0.0064 & 0.0004 \\
\hline 137 & Cyclooctane, 1,5-dimethyl- & $21328-57-4$ & 0.0063 & 0.0012 \\
\hline 119 & Octane, 3,4-dimethyl- & $15869-92-8$ & 0.0062 & 0.0067 \\
\hline 135 & Cyclohexane, 1-methyi-3-propyi- & $4291-80-9$ & 0.0062 & 0.0015 \\
\hline 227 & Alkanol & & 0.0061 & 0.0041 \\
\hline 139 & 3-Hexene, 2,2,5,5-tetramethyl- and others & & 0.0061 & 0.0160 \\
\hline 147 & Nonane, 4,5-dimethyl- & $17302-23-7$ & 0.0061 & 0.0054 \\
\hline 177 & 3-Undecene, 8-methyl- & & 0.0060 & 0.0031 \\
\hline 103 & Styrene & $100-42-5$ & 0.0059 & 0.0008 \\
\hline 143 & Mixture & & 0.0058 & 0.0045 \\
\hline 68 & Mixture & & 0.0057 & 0.0005 \\
\hline 240 & C7-Cyclohexane & & 0.0056 & 0.0008 \\
\hline 205 & Phenol, 4-(1,1-dimethylethyl)- and others & & 0.0055 & 0.0005 \\
\hline 10 & 2-Pentene, $(Z)$ & $627-20-3$ & 0.0053 & 0.0106 \\
\hline 162 & Cyclopropane, 1-butyl-1-methyl-2-propyl- & $41977-34-8$ & 0.0049 & 0.0047 \\
\hline 129 & Cyclohexane, 1-methyl-4-(1-methylethyl) & $6069-98-3$ & 0.0049 & 0.0022 \\
\hline 247 & 5-Undecanone, 2-methyl- & $50639-02-6$ & 0.0048 & 0.0034 \\
\hline 206 & Undecane, 2,4-dimethyl- & $17312-80-0$ & 0.0048 & 0.0005 \\
\hline 157 & 2-Nonanone & $821-55-6$ & 0.0047 & 0.0037 \\
\hline 243 & Tetradecane, 4,11-dimethyl- & $55045-12-0$ & 0.0047 & 0.0055 \\
\hline 256 & 1-Hexadecene & $629-73-2$ & 0.0047 & 0.0015 \\
\hline 125 & Cycloheptane, methoxy and others & & 0.0047 & 0.0037 \\
\hline
\end{tabular}


WHC-SD-WM-ER-419 REV. 2

\begin{tabular}{|c|c|c|c|c|}
\hline$\underset{\#}{\text { Cmpd }}$ & Compound & $\begin{array}{c}\text { CAS }^{1} \\
\text { Number }\end{array}$ & $\begin{array}{l}\text { Average } 2 \\
\left(\mathrm{mg} / \mathrm{m}^{3}\right)\end{array}$ & $\begin{array}{r}\text { Standard } \\
\text { Deviation } \\
\left(\mathrm{mg} / \mathrm{m}^{3}\right)\end{array}$ \\
\hline 141 & Mixture & & 0.0046 & 0.0009 \\
\hline 138 & 1-Octanol, 2 butyl- and others & & 0.0046 & 0.0004 \\
\hline 78 & Alkene & & 0.0045 & 0.0053 \\
\hline 219 & Alkane & & 0.0044 & 0.0050 \\
\hline 55 & 3-Heptene, (E) & $14686-14-7$ & 0.0043 & 0.0029 \\
\hline 19 & 1,3-Butadiene, 2-methyl- & $78-79-5$ & 0.0043 & 0.0087 \\
\hline 50 & Cyclohexene & $110-83-8$ & 0.0043 & 0.0051 \\
\hline 248 & Pentadecane & $629-62-9$ & 0.0043 & 0.0028 \\
\hline 155 & Cyclohexane, 2,4-diethyl-1-methyl- & $61142-70-9$ & 0.0042 & 0.0062 \\
\hline 185 & Alkenyl-cyciopentane & & 0.0041 & 0.0003 \\
\hline 272 & Hexadecanoic acid, 1-methylethyl ester & $142-91-6$ & 0.0041 & 0.0029 \\
\hline 170 & 1-Undecene, 4-methyl- & $74630-39-0$ & 0.0039 & 0.0149 \\
\hline 136 & 3-Hexene, 3-ethyl-2,5-dimethyl- & $62338-08-3$ & 0.0039 & 0.0006 \\
\hline 86 & Pyridine, 3-methyl- & $108-99-6$ & 0.0039 & 0.0044 \\
\hline 161 & Furan, 3-(1,1-dimethylethyl)2,3-dihydro- & $34314-82-4$ & 0.0038 & 0.0008 \\
\hline 178 & Naphthalene, decahydro, 1,5-dimethyl- & $66552-62-3$ & 0.0036 & 0.0045 \\
\hline 203 & 1-Tridecene & $2437-56-1$ & 0.0035 & 0.0003 \\
\hline 75 & $\begin{array}{l}\text { 2,4-Hexadiene, 3-methyl- and } \\
\text { C2-Cyclohexane }\end{array}$ & & 0.0035 & 0.0041 \\
\hline 145 & C5-Cyclohexane & & 0.0034 & 0.0037 \\
\hline 187 & Undecane, 3-methyl- & $1002-43-3$ & 0.0034 & 0.0004 \\
\hline 160 & 5-Undecene & $4941-53-1$ & 0.0034 & 0.0021 \\
\hline 26 & C6-alkene & & 0.0032 & 0.0064 \\
\hline 49 & 1-Hexene, 3,4-dimethyl- & $16745-94-1$ & 0.0032 & 0.0037 \\
\hline 166 & 3-Decyne & $2384-85-2$ & 0.0032 & 0.0025 \\
\hline 46 & 2-Butanone, 3-methyl- & $563-80-4$ & 0.0031 & 0.0063 \\
\hline 114 & Cyclohexane, 1-propenyl- & $5364-83-0$ & 0.0030 & 0.0063 \\
\hline 80 & Ethane, 1,2-dimethoxy- & $110-71-4$ & 0.0030 & 0.0060 \\
\hline 189 & Cyclopentane, 1-pentyl-2-propyl- & $62199-51-3$ & 0.0030 & 0.0004 \\
\hline 263 & 2-Pentadecanone, 6,10,14-trimethyl- & $502-69-2$ & 0.0029 & 0.0022 \\
\hline \multicolumn{5}{|c|}{52} \\
\hline
\end{tabular}


WHC-SD-WM-ER-419 REV. 2

\begin{tabular}{|c|c|c|c|c|}
\hline$\underset{\#}{C \text { Cmpd }}$ & Compound & $\begin{array}{l}\text { CAS }^{+} \\
\text {Number }\end{array}$ & $\begin{array}{l}\text { Average }^{2} \\
\left(\mathrm{mg} / \mathrm{m}^{3}\right)\end{array}$ & $\begin{array}{l}\text { Standard } \\
\text { Deviation } \\
\left(\mathrm{mg} / \mathrm{m}^{3}\right)\end{array}$ \\
\hline 176 & C2-decahydronaphthalene & & 0.0026 & 0.0025 \\
\hline 265 & 1-Hexadecanol & $36653-82-4$ & 0.0024 & 0.0018 \\
\hline 220 & Decane, 2,3,8-trimethyi- & $62238-14-6$ & 0.0024 & 0.0047 \\
\hline 241 & Tridecane, 5-propyl- & $55045-11-9$ & 0.0023 & 0.0016 \\
\hline 70 & 1-Octene & $111-66-0$ & 0.0022 & 0.0026 \\
\hline 255 & 5-Undecanone, 2-methyl- & $50639-02-6$ & 0.0021 & 0.0015 \\
\hline 62 & Hexane, 2,4-dimethyl- & $589-43-5$ & 0.0021 & 0.0024 \\
\hline 106 & 1-Hexene, 3,5,5-trimethyl- & $4316-65-8$ & 0.0020 & 0.0040 \\
\hline 192 & C3-decahydronaphthaiene & & 0.0020 & 0.0041 \\
\hline 237 & 1-Tetradecanol & $112-72-1$ & 0.0019 & 0.0037 \\
\hline 112 & 2-Heptanol, 2-methyl- and others & & 0.0019 & 0.0102 \\
\hline 183 & Undecane, 2,4-dimethyl- and others & & 0.0019 & 0.0022 \\
\hline 180 & C13-alkene & & 0.0019 & 0.0013 \\
\hline 254 & Cyclohexane, decyl & $1795-16-0$ & 0.0017 & 0.0011 \\
\hline 126 & Alkyi-cyclohexene & & 0.0017 & 0.0037 \\
\hline 238 & C9-Cyclopentane & & 0.0016 & 0.0032 \\
\hline 266 & Hexanedioic acid, dioctyl ester & $123-79-5$ & 0.0016 & 0.0031 \\
\hline 56 & 2-Butanol & $78-92-2$ & 0.0015 & 0.0030 \\
\hline 128 & C4-Cyclohexane & & 0.0014 & 0.0033 \\
\hline 108 & $\begin{array}{l}1 \mathrm{R}, 2 \mathrm{~T}, 4 \mathrm{C}, 5 \mathrm{~T}-1,2,4,5 \text {-Tetramethyicyclo- } \\
\text { hexane }\end{array}$ & & 0.0013 & 0.0030 \\
\hline 250 & 3-Hexadecene, (Z)- & $34303-81-6$ & 0.0012 & 0.0014 \\
\hline 211 & C8-Cyclohexane & & 0.0012 & 0.0023 \\
\hline 76 & Unknown & & 0.0012 & 0.0025 \\
\hline 212 & Mixture & & 0.0012 & 0.0025 \\
\hline 107 & 1,1,2,3-Tetramethylcyclohexane & $6783-92-2$ & 0.0012 & 0.0028 \\
\hline 267 & Mixture & & 0.0012 & 0.0025 \\
\hline 48 & 1,4-Hexadiene & $592-45-0$ & 0.0012 & 0.0023 \\
\hline 209 & 1-Dodecanol & $112-53-8$ & 0.0011 & 0.0023 \\
\hline 260 & Octadecane & $593-45-3$ & 0.0011 & 0.0013 \\
\hline
\end{tabular}


WHC-SD-WM-ER-419 REV. 2

\begin{tabular}{clrrr}
\hline $\begin{array}{c}\text { Cmpd } \\
\#\end{array}$ & Compound & $\begin{array}{c}\text { CAS }^{1} \\
\text { Number }\end{array}$ & $\begin{array}{c}\text { Average }^{2} \\
\left(\mathrm{mg} / \mathrm{m}^{3}\right)\end{array}$ & $\begin{array}{c}\text { Standard } \\
\text { Deviation } \\
\left(\mathrm{mg} / \mathrm{m}^{3}\right)\end{array}$ \\
\hline \hline 261 & Siloxane & & 0.0011 & 0.0012 \\
61 & C7-alkene & & 0.0011 & 0.0022 \\
82 & Ethene, tetrachloro- & $127-18-4$ & 0.0011 & 0.0021 \\
85 & Alkene & & 0.0011 & 0.0021 \\
67 & 1-Heptene, 3-methyl-and others & & 0.0010 & 0.0021 \\
120 & Benzene, propyl- & $103-65-1$ & 0.0010 & 0.0065 \\
264 & Pentadecanoic acid & $1002-84-2$ & 0.00097 & 0.00193 \\
190 & Alkene & & 0.00098 & 0.00196 \\
269 & 2-Pentadecanone, 6,10,14-trimethyl- & $502-69-2$ & 0.00098 & 0.00113 \\
134 & Cyclopentane, (2-methylbutyl)- & $53366-38-4$ & 0.00094 & 0.00266 \\
271 & Hexadecane, 2,6,10,14-tetramethyl- & $638-36-8$ & 0.00055 & 0.00109 \\
268 & 2-Heptadecanone & $2922-51-2$ & 0.00042 & 0.00085 \\
Sum of tentatively identified compounds: & & 8.60 & \\
\hline \hline
\end{tabular}

$1 \mathrm{CAS}=$ Chemical Abstract Service.

2 Average of 4, 4-L TST samples analyses, values listed are estimates. 